\title{
HET HUIS DE SPIJKER AAN DE PENSMARKT IN GENT
}

\author{
Jelle Moens
}

\begin{abstract}
"En wij zouden hier te Gent onze schouders minachtend ophalen voor een zoo goed bewaarden romaanschen gevel als den Spijker in den Hooiaard, in een stad die bogen kan op een Gravensteen en een Sint-Baafsabdij ${ }^{1}$ "
\end{abstract}

\section{Inleiding}

Als eindverhandeling binnen de opleiding master in de Monumenten- en Landschapszorg (Hoger Instituut voor Architectuurwetenschappen Henry van de Velde, Antwerpen) schreef ik een bouwhistorische studie over het graanstapelhuis de Spijker in Gent. Het pand behoort tot het selecte gezelschap van middeleeuwse stenen stadshuizen, de zogenaamde Stenen, die door de diensten Stadsarcheologie en Monumentenzorg van de Stad Gent de afgelopen decennia veelvuldig onder de aandacht werden gebracht. De Spijker aan de Pensmarkt (afd. 3, sectie C, percelen 15d, 17b, 18b, 19 en 22a) werd echter nog niet ten gronde onderzocht maar schrijft reeds eeuwen zijn hoofdstuk in de stadsgeschiedenis neer ${ }^{2}$ (afb.1).

\section{De ligging nabij de middeleeuwse Leiehaven}

De oorsprong van de middeleeuwse stad Gent is terug te voeren op een gebied van ruim zeven hectare dat gelegen was binnen een omwalling die aansloot op de Schelde ${ }^{3}$. Deze vroegste handelsplaats kon zich door zijn ligging aan de verbreding of vroegere bocht van de Schelde beroepen op een haven die bekend staat als portus Ganda. De havenactiviteiten zorgden naast een economische stimulans ook voor een demografische groei, wat resulteerde in het

1 Artikel uit het Volksbelang (6 april 1904), IN: UGent, Fonds Vliegende Bladen, III S 29, Spijker Hooiaard.

2 Zie M. C. LALEMAN, P. RAVESCHOT, Inleiding tot de studie van de woonhuizen te Gent, periode 1000-1300: de kelders, Brussel, 1991, p. 113 en K. DE VINCK, De metamorfosen van een stadsgezicht: de Graslei en de Koornlei te Gent van de Middeleeuwen tot vandaag, Gent, 1976, p. 32.

3 M.C. LALEMAN, De eerste middeleeuwse stad, IN: De Gentse portus aan de Reep: een historische verkenning, (Uitgave Provincie Oost-Vlaanderen), Gent, 2004, p. 8-11. 


\section{JELLE MOENS}

overschrijden van de eerste omwalling in de loop van de tiende eeuw ${ }^{4}$. De handelsnederzetting strekte zich voortaan uit in westelijke richting tot aan en over de Leie, en besloeg een areaal van tachtig hectare, dat omstreeks 1100 werd besloten door een grachtengordel.

In de dertiende eeuw ontplooide zich een binnenhaven aan de Leie (Tusschen Brugghen) waar de graanhandel tot volle bloei kwam. De havenactiviteiten weerspiegelden zich in de directe omgeving waar gildenhuizen, herbergen en handelshuizen werden ingericht. Vlak bij verwierf een open plein naam als Korenmarkt. In het tolhuisje controleerden de stapelheren of het privilege van de graanstapel correct werd nageleefd. Dit voorrecht leidde tot het inrichten van geschikte bergplaatsen waar het graan gedurende een welbepaalde periode kon worden bewaard. Een dergelijke berging waar het graan lag opgestapeld was de Spijker aan de Hooiaard.

\section{Pensmarkt of Hooiaard?}

Tot in de negentiende eeuw werd de Spijker gesitueerd aan de Hooiaard. De vroegste vermelding van deze 'brede straat' gaat terug tot 1297-1300, al zal deze locatie reeds eerder bestaan hebben. In het toponiem Hooiaard duidt het suffix '-aard' op aanlegplaats. De plaats kan dus letterlijk geïnterpreteerd worden als een aanlegplaats voor schepen op de Leie, waar het hooi werd gelost dat daar op de markt werd gebracht.

Rond het midden van de negentiende eeuw vond het toponiem 'Pensmarkt' ingang, waarmee de verbindingsstraat tussen de Hooiaard en de Groentenmarkt en de verbindingsas tussen de Graslei en de Groentenmarkt thans wordt benoemd. De straatnaam verwijst naar de eertijds bloeiende handel in 'pens'. De beenhouwers gebruikten daartoe slachtafval als koemaag en koelongen die werden gekapt, gekookt en nadien in schoteltjes gegoten om te stollen $^{5}$. Pens was, gezien de dure vleesprijzen, typische armemensenkost. $\mathrm{Na}$ de Tweede Wereldoorlog, ten gevolge van de opkomst van de bereide vleeswaren en de verhoging van de welstand, verdween de pens uit vele slagerijen. 


\section{Het Groot Vleeshuis en de penshuisjes}

De handel in pens wijst indirect op de nabijheid van het vleeshuis, gelegen ten noorden van de Spijker ${ }^{6}$. De bouw van het huidige Groot Vleeshuis startte in 1407 , toen de schepenen van de Keure instemden met de vraag van de vleeshouwers om een nieuw, voldoende groot pand op te trekken waarin naast een verkoopszaal ook een vergaderruimte en een eventuele kapel konden ondergebracht worden. De stedelijke opperbouwmeester Gillis de Sutter zorgde er op verzoek van de gildenlieden voor dat de vleesverkoop ongehinderd kon voortgaan door de oude, verwaarloosde vleeshalle geleidelijk aan af te breken en herop te bouwen. Het statige Groot Vleeshuis, met gevels in Lediaanse kalkzandsteen, werd opgeleverd in 1419. De nieuwbouw had als direct gevolg voor de Spijker dat de noordgevel niet langer vrij stond. Alle muuropeningen werden gedicht, een ingreep waarvan de sporen nog steeds duidelijk merkbaar zijn.

In 1543 werden tegen de zuidoostgevel van het Groot Vleeshuis zestien penshuisjes aangebouwd. In deze winkeltjes werden afvalproducten zoals ingewanden, darmvet en andere resten van slachtvee aan de man gebracht die binnen niet mochten verkocht worden. In 1785 werden er plannen gemaakt om de vervalten penshuisjes af te breken en te vervangen door zestien nieuwe huisjes in Lodewijk XVI-stijl, naar een ontwerp van J. d'Huyvetter, directeur van de Gentse Academie voor Schone Kunsten ${ }^{7}$. Dit sierlijke ontwerp werd echter nooit uitgevoerd. De teloorgang van de bouwvallige vleeshalle en de verhuis van de vleeshouwers naar de vismijn aan het Sint-Veerleplein in de loop van de negentiende eeuw, droegen bij tot het complete verval van de penshuisjes. Hun sloop in 1884 leek onafwendbaar gezien hun erbarmelijke toestand. In het vooruitzicht van de Wereldtentoonstelling van 1913 werd besloten het Groot Vleeshuis, penshuisjes inbegrepen, te restaureren en te reconstrueren naar hun toestand van voor 1744. De architect die zich tussen 1912 en 1914 over dit project ontfermde was Ernest Van Hamme, die in 1904 en 1911 ook de Spijker had gerestaureerd. ${ }^{8}$

$6 \quad$ Het 'Groot' Vleeshuis onderscheidt zich van het 'Klein' Vleeshuis dat zich achtereenvolgens bevond op de hoek van de Brabantdam en de Sint-Jansvest, op de hoek van de Vogelmarkt en de Kortedagsteeg en in de voormalige Wolweverskapel, eveneens in de Kortedagsteeg. UIT: Van alle markten thuis! Het Groot Vleeshuis en de Pensenmarkt, IN: Ghendtsche Tydinghen, 1989, 5, p. 266.

7 R. DE HERDT, De bouwgeschiedenis van een overdekte markt: het Groot Vleeshuis te Gent, IN: J. VAN DE WIELE, (e. a.), De markt. Economisch forum en kloppend hart van agrarische, stedelijke en industriële maatschappijen, Gent, 1988, p. 89.

$8 \quad$ R. DE HERDT, De bouwgeschiedenis van het Groot Vleeshuis, Gent, s. d. [Uitgave van de Gentse Vereniging voor Industriële Archeologie en Textiel], Van alle markten thuis! Het Groot Vleeshuis en de Pensenmarkt, IN: Ghendtsche Tydinghen, 1989, 5, pp. 266-271. 


\section{JELLE MOENS}

\section{Het bijgebouwtje naast de Spijker}

Aan de noordgevel van de Spijker staat een bijgebouwtje ter hoogte van de poort van het Groot Vleeshuis. Een omschrijving uit 1655 leert dat het gaat om $t$ cleen huyseken daeranne ghemaeckt, wesende eene braderie, soo 't selve geghenwordich wort ghebruyckt bij dhoirs van Adriaen Steemaere ${ }^{9}$. De term braderie moet hier geïnterpreteerd worden als een verkoopsstalletje waar gebraden vlees werd verkocht ${ }^{10}$. De verwijzing naar het cleen huyseken komt regelmatig terug. Zo ook in de stadsrekening van 1732 waarbij de erfgenamen van Jan van de Kerchove 2 schellingen 6 groten betalen voor dhuere van een plaetse ande endeldeure van het groot vleeschuys ghenaempt den Spyckere, daer oppe ghestaen heeft een hauten huyseken ter conditie als bij een pachtynghe ${ }^{11}$. In 1744 richtte Joanne Lantheere, toenmalig herbergierster van 'Het Goude Mandeken', een brief aan de schepenen van de Keure met de vraag dat zij den aftreck ten straeten comende tot aende eerste deure van tselve vleeschhuys tgone als ruine menacerende ${ }^{12}$, is moeten afgebroken worden, geerne souden laeten herbouwen ten hooghde van eene stagie, ende ten grootte ghelyck als tselve is gheweest ${ }^{13}$. De toestemming werd haar verleend, mits ze zich aan de gestelde voorwaarden hield. Enkele decennia later, in 1770, richtte de nieuwe eigenaar, Pieter Geeraerts, zich ook tot dezelfde schepenen. Hij had graag het hauten huyseken ofte logie afgebroken gezien en wou het laeten veranderen ende derigeren in steen volghens de annexe modelle ${ }^{14}(\mathrm{afb} .2)$. De ontwerptekening toont de voorgevel van een huisje met één bouwlaag. Het bouwwerk zou opgetrokken worden in baksteen en een leien dak dragen. De deur met bovenlicht en het venster vormen een eenheid door het gebruik van een geriemde omlijsting. Een plattegrond toont dat rechtover de deuropening een haard voorzien was en dat in de linkse zijmuur nog een vensteropening zat. Het is niet bekend of dit plan werd gerealiseerd maar enkele decennia later behoorde het vaute caemerken bij de herberg 'Het Goude Mandeken', zoals mag blijken uit de boedelstaat van Joannes Franciscus Geeraerts ${ }^{15}$.

$9 \quad$ RAG., Oud Archief, Rijke Gasthuis (Cijnsboeken van gronden te Gent), nr. 184 , f. 459r.

10 E. VERWIJS, J. VERDAM, Middelnederlandsch woordenboek, deel 1, p. 1412.

11 SAG., Oud Archief, Reeks 400 (Stadsrekeningen), nr. 299, Register 17321733, f. 23r.

12 Aftreck= een bezitting die aan iemand toebehoort of aan iets verbonden is, UIT: E. VERWIJS, J. VERDAM, Middelnederlandsch woordenboek, deel 1, p. 286.

13 SAG., Oud Archief, Reeks 535 (Huizen- Bouwaanvragen en veranderingswerken), nr. 231 (1) Pensmarkt.

14 SAG., Oud Archief, Reeks 535 (Huizen- Bouwaanvragen en veranderingswerken), nr. 103 (7) Hooiaard.

15 SAG., Oud Archief, Reeks 330 (Nieuwe register staeten van goeden), nr. 303, Register 3 september tot 29 december 1792. 


\section{DE SPIJKER AAN DE PENSMARKT}

Op een foto die dateert van 1898 is te zien dat het huisje een blinde zijgevel heeft die, net zoals de voorgevel van de Spijker, bepleisterd is ${ }^{16}$ (afb. 3). Vermoedelijk vormde de restauratie van het Groot Vleeshuis in 1897 de aanleiding om het gebouwtje kort nadien van zijn pleisterlaag te ontdoen. Het bakstenen gebouwtje onderging een historiserende restauratie waarbij in de voorgevel twee kruisvensters kwamen te zitten. In de bovenlichten werden dievenstaven geplaatst, de benedenlichten werden afgesloten met luiken die waren opgehangen aan accoladevormige hengsels. Voor de monelen en lintelen werd een witte kalkzandsteen gebruikt. Onderaan de voorgevel werd een spaarboog ingemetseld om de fundering te beperken.

\section{De Spijker en het stapelrecht}

De benaming 'spijker' is afgeleid van het Latijnse spicarium wat zoveel betekent als een plaats waar spicare (aren) worden opgeborgen ${ }^{17}$. Deze connotatie is nog steeds merkbaar in het Duitse woord Speicher waarmee een pakhuis of magazijn in de betekenis van een (graan- of koren-) schuur wordt bedoeld. Het zelfstandig naamwoord 'spijker' is naar geslacht zowel mannelijk als onzijdig. Naar analogie met het bronnenmateriaal werd evenwel gekozen te schrijven over de Spijker.

Het gegeerde privilege van het stapelrecht lag aan de basis van het succesverhaal dat de graanhandel in de Gentse stadsgeschiedenis zou neerschrijven. Alle handelswaren uit het zuiden die bestemd waren voor het graafschap Vlaanderen of voor het hertogdom Brabant werden aangevoerd langs de Schelde of de Leie. Reeds op het einde van de twaalfde eeuw nam de aanvoer van Artesisch graan een hoge vlucht ${ }^{18}$, maar pas in de loop van de veertiende eeuw werden geleidelijk aan reglementen voor de graanmarkt en de stapel in een vaste vorm gegoten ${ }^{19}$. Wanneer het voorrecht ontstaan is, is niet bekend. Het privilege van het stapelrecht hield in dat alle schepen, beladen met graan, die Gent doorkruisten op weg naar hun bestemming of Gent zelf als eindpunt hadden, verplicht werden een welbepaalde hoeveelheid van hun vracht af te staan en te laten stapelen ${ }^{20}$. In Gent gold het privilege enkel op de harde graansoorten, zoals tarwe en rogge.

16 SAG., Reeks SCMS (Foto's), doos 165, Hooiaard, nr. 2395.

17 E. VERWIJS, J. VERDAM, Middelnederlandsch woordenboek, deel 7, p. 1730.

18 M. C. LALEMAN, P. RAVESCHOT, Inleiding tot de studie van de woonhuizen te Gent ..., p. 224.

19 J. DECAVELE, R. DE HERDT, N. DECORTE, Gent op de wateren en naar de zee, p. 116.

20 K. DE VINCK, De metamorfosen van een stadsgezicht ..., p. 30. 


\section{JELLE MOENS}

Bij aankomst in de Leiehaven moest een met graan beladen schip verplicht aanmeren aan de huidige Graslei. Onmiddellijk werd melding gemaakt van de hoeveelheid aangevoerd graan en werd de naam van de koopman geregistreerd. Vervolgens kreeg de schipper de toestemming om een kwart van de lading, gemeten door de korenmeters, te laten lossen door de vrije pijnders die het stapelden tusschen brugghen ende nievers elders ${ }^{21}$. Deze nadrukkelijke beperking moet gezien worden als een beklemtoning van de nauwe relatie die de binnenhaven onderhield met de graanstapel. Het is echter bekend dat de inrichting van de stapelplaatsen niet beperkt bleef tot de beide Leie-oevers. Eenmaal een vierde deel van de scheepslading was afgemeten en gelost, mocht de schipper doorvaren of zijn resterende vracht in de stad verkopen. Langer halt houden in de haven was uit den boze: binnen de drie dagen na het lossen moesten de schepen de Leiehaven verlaten ${ }^{22}$.

De ambtenaren die bevoegd waren voor de correcte afhandeling van de transactie stonden bekend als de stapelheren of stapelhouders. Zij controleerden de werkzaamheden van de korenmeters en hielden nauwgezet de administratie bij in de zogenaamde stapelboeken om zo een overzicht te krijgen van de hoeveelheid gestapeld graan. Dat graan of onvrij koren bleef acht tot veertien dagen liggen op én van de talrijke zolders. Na het verlopen van deze periode werd het graan gelost en eerst, gedurende acht dagen, te koop aangeboden aan de handelaars van de stad. Nadien kregen de andere inwoners de kans om het vrijgegeven graan op de Korenmarkt aan te kopen.

De pijnders, die de talloze zakken uitdroegen, hadden het geluk niet al te ver te moeten lopen. De bergplaatsen lagen om praktische redenen alle in de nabijheid van de haven en de Korenmarkt. Bepaalde huisnamen zoals Korenstapelhuis (Graslei) en Spijker (Pensmarkt) geven reeds een indicatie van de voormalige functie. Ook het huis De Beerie aan de Graslei was een stapelplaats, beer betekent namelijk zoveel als graan of zaad ${ }^{23}$. De graanhandelaars werden daarom ook beerielegghers genoemd, hun magazijnen de beeriën. Het graan dat werd gestapeld in de huizen langs de Leie, kwam terecht in zogenaamde herberghen ter Leye ${ }^{24}$. Het is echter verkeerd te denken dat het graan uitsluitend werd gestapeld in speciaal daartoe opgerichte panden. Heel wat particulieren die een stenen woning bezaten, speelden handig in op de vraag naar stapelruimten. De stevige constructie van hun Stenen liet toe de zolderruimten vol te stouwen met graan.

21 J. DECAVELE, R. DE HERDT, N. DECORTE, Gent op de wateren en naar de zee, p. 120.

22 J. DECAVELE, R. DE HERDT, N. DECORTE, Gent op de wateren en naar de zee, p. 122.

23 K. DE VINCK, De metamorfosen van een stadsgezicht ..., p. 32.

24 J. DECAVELE, R. DE HERDT, N. DECORTE, Gent op de wateren en naar de zee, p. 123. 


\section{DE SPIJKER AAN DE PENSMARKT}

Het spreekt voor zich dat dit privilege enkele voordelen met zich meebracht. De grote hoeveelheden graan, die regelmatig werden aangevuld en ververst, kwamen tegemoet aan de lokale vraag waardoor de graanprijs steeds laag kon gehouden worden. De lokale bevolking kon beroep doen op de graanreserve in tijden van misoogsten, oorlogen en sociale troebelen. Tevens lokte het stapelrecht heel wat handelaars naar de stad zodat ook de lokale handel er wel bij voer.

\section{De relatie met de Gentse lazarij}

De oudste vermelding van de Spijker werd teruggevonden in een oorkonde van het godshuis Sint-Jan en Sint-Pauwel uit 1396. Hierin werd een erfelijke rente vastgesteld ghecocht ieghen tgasthuus ter lazerien binnen Ghend, besedt up den spijkere neffens tVleeschuus ${ }^{25}$. Het Gasthuis Onze-Lieve-Vrouw ter Lazarije, dat werd geticht omstreeks 1146, was een stedelijke instelling waarvan het hoogste gezag berustte bij de Gentse schepenen ${ }^{26}$. De dagelijkse leiding was in handen van een meester of meesteres die aan het hoofd stond van de religieuze gemeenschap van broeders en zusters van het gemene leven 27. Ook al werd de christelijke caritas hoog in het vaandel gedragen, toch bleef de zorg voor de getroffen slachtoffers beperkt tot de poorters van de stad Gent.

Het Gasthuis kon zich beroepen op enkele voorrechten om zich van haar inkomsten in natura verzekerd te weten. De Gentse schepenen verschaften hen ondermeer het lepelrecht. Hierdoor kreeg de instelling van iedere zak graan hetzij van taerwe, rogghe, raepsaet en alle andere manieren van saden die in Gent geleverd en gemeten werd met de drooge mate drie koperen lepels per mud toegewezen $^{28}$. Daarnaast bezat de leprozerie ook het strekelrecht: al wat van de gevulde maat bij het effenstrijken met de strekel of strijkstok afviel, kwam ten goede aan het Gasthuis ${ }^{29}$. Het is binnen deze context dat hun eigendom aan de Hooiaard moet gezien worden. In een schepenakte van 18 juni 1492 waarin de

25 J. B. BETHUNE, A. VAN WERVEKE, Het godshuis van Sint-Jan en SintPauwel te Gent, bijgenaamd de Leugemeete: Oorkonden, uitgegeven door Mr. J. B. Baron Bethune en A. Van Werveke, Gent, 1902, p. 26.

26 Ch. DE CONINCK, Geschiedenis van de Gentse Leprozerie. Het Rijke Gasthuis. Vanaf de stichting tot circa 1370, Gent, UGent (onuitgegeven licentiaatverhandeling), 1965, p. 42.

27 G. MARECHAL, Lepra en leprozen, IN: J. VAN KEYMEULEN, M. ADRIAEN, G. MARECHAL, In der Sieker Dienste. Heruitgave van de oudste ambtelijke tekst in het Nederlands: de 'statuten van de leprozerie van Gent' (1236), (Uitgave Gent Cultuurstad), Gent, 2003, p. 41.

28 Ch. DE CONINCK, Geschiedenis van de Gentse Leprozerie. Het Rijke Gasthuis ..., p. 218.

29 Ch. DE CONINCK, ibidem. 


\section{JELLE MOENS}

verkoop van het aanpalende huis $\mathrm{De}$ Croone geregistreerd staat, wordt beschreven hoe de broeders het medegebruik hebben over een gang naast de Spijker: ... lanx den ghanghe tot huerer kamere met eene deurkine duer den ghevele binnen den spijkere omme heurlieden graen dat zij ten haerde ende elder vergaderen te legghene ende logierene ... ${ }^{30}$. De broeders van het Gasthuis beheerden dus zelf meerdere stapelruimten, waaronder de Spijker aan de Hooiaard. In de Spijker was er bovendien een ruimte voorzien, een zogenaamde kamere, waar de broeders naar alle waarschijnlijkheid hun administratieve verplichtingen als beheerders van het graanstapelhuis vervulden.

De vraag stelt zich hoe de Spijker in het bezit kwam van het Gasthuis. Hierbij kunnen twee hypotheses vermeld worden: ofwel was het pand reeds van bij zijn oorsprong in het bezit van de leprozerie, ofwel werd het pand in een jongere fase verworven. In het eerste geval lijkt het niet ondenkbaar dat de instelling als bouwheer kon rekenen op de steun van het Gentse stadsbestuur en van enkele welgestelde poorters die hun zielenheil wensten veilig te stellen door te investeren in de bouw van een graanstapelhuis. Bij het tweede geval kan verwezen worden naar de analoge situatie van enkele stapelhuizen, waaronder het Korenstapelhuis en huis De Beerie, die aanvankelijk particulier bezit waren en pas in een jongere fase werden beheerd door een instelling ${ }^{31}$. Bij deze veronderstelling kon een eventuele transactie op twee manieren verlopen. Een eerste mogelijkheid bestaat erin dat een kapitaalkrachtige poorter getroffen werd door lepra en een onderkomen vond in de leprozerie. De leproos werd bij zijn intreden in het Gasthuis verplicht afstand te nemen van al zijn bezittingen, die hij niet meer weer kreeg wanneer hij langer dan één jaar en één dag in de leprozerie verbleef ${ }^{32}$. Indien de leproos ongehuwd was, ging heel zijn bezit naar het Gasthuis, zoniet mochten zijn vrouw en kinderen ook hun rechten laten gelden. Een tweede mogelijkheid gaat er van uit dat de relatie tussen het lepelrecht en het stapelrecht meer geïnstitutionaliseerd van aard was. Volgens een oorkonde van 31 juli 1478 zou het lepelrecht reeds van bij de stichting (omstreeks 1146) toevertrouwd zijn aan het Gasthuis ${ }^{33}$. Het lijkt niet ondenkbaar dat het Gasthuis van meet af aan bewust stapelruimten verwierf zodat ze er zelf op kon toezien dat haar voorrechten correct werden nageleefd. Vermits het wereldlijke gezag dominant was binnen het bestuur van de instelling en de leden uit de drie bestuursniveaus (schepenen, voogden en meester(es)) uit gegoede, zoniet adellijke milieus stamden, is het niet

30 SAG., Oud Archief, Reeks 301 (Jaarregisters van de Keure. Acten en contracten), nr. 61 (1490-1492), deel 1491-1492, f. 65 r.

31 M. C. LALEMAN, De Gentse Stenen: getuigen van handel in laken, graan en bouwstenen (11de-14de eeuw), IN: Rotterdam Papers, 1992, nr. 7, p. 68.

32 Ch. DE CONINCK, W. BLOCKMANS, Annalen van de Belgische Vereniging voor Hospitaalgeschiedenis, 1967, V, p. 19.

33 Ch. DE CONINCK, Geschiedenis van de Gentse Leprozerie. Het Rijke Gasthuis ..., p. 218. 


\section{DE SPIJKER AAN DE PENSMARKT}

ondenkbaar dat sociale contacten aan de grondslag van een verkoop of een schenking van de Spijker lagen.

\section{Het voorhuis van de Spijker}

De oudste, nog aanwezige, bouwfase valt te situeren in het zogenaamde voorhuis van de Spijker dat zichtbaar is van aan de Pensmarkt. Deze rechthoekige structuur in Doornikse steen is 18 meter breed en 10 meter diep, en sluit naar constructieconcept aan bij de zaalstructuur die onder meer werd gebruikt bij middeleeuwse kerken, hallen en schuren. Het pand bestaat uit drie bouwlagen met een zolderverdieping onder het zadeldak. Hierbij dient opgemerkt dat het loopniveau van de begane grond aanzienlijk lager ligt dan het straatniveau. Onderzoek ter zake door de Dienst Stadsarcheologie van de Stad Gent wees uit dat de archeologica in het ophogingspakket konden gedateerd worden in de late dertiende en het begin van de veertiende eeuw ${ }^{34}$. De ophoging van de Hooiaard mag dus als een terminus ante quem beschouwd worden: de bouw van dit voorhuis gaat terug tot voor deze periode.

Over het bestaan van een kelder onder deze halfondergrondse verdieping zijn geen nadere gegevens bekend. Interessant te vermelden is dat bij het vernieuwen van de tegelvloer in café 'Het Spijker' (Pensmarkt 3-5) een knoppenkapiteel, vervaardigd uit Doornikse steen, werd aangetroffen dat evenwel zonder enige melding of wetenschappelijk onderzoek op de toog werd geplaatst als curiositeit. Vermits deze locatie in oorsprong een drassige oever was, lijkt een fundering met spaarbogen die eventueel in een jongere fase werd ingericht als kelderruimte niet onmogelijk.

\section{Stenen doos, ...}

Het zware bouwmateriaal geeft aan de Stenen doorgaans een massief en gesloten karakter maar in het geval van het voorhuis wordt dit gecompenseerd door de talrijke doorbrekingen. Het muurwerk van de voor- en de achtergevel wordt geritmeerd door negen traveeën die per bouwlaag een doorbreking vertonen. In regel gaat het steeds om schouderboogvormige vensteropeningen, met uitzondering van de segmentboogvormige doorbrekingen op de begane grond en op de eerste verdieping in de voorgevel ( $\mathrm{afb}$. 4). De doorbrekingen in de eerste bouwlaag bleken alle in oorsprong gelijkgrondse toegangen te zijn $^{35}$. Bij het verwijderen van de pleisterlaag tijdens de restauratiewerken in

34 M. C. LALEMAN, P. RAVESCHOT, Inleiding tot de studie van de woonhuizen te Gent ..., p. 149.

35 M. C. LALEMAN, P. RAVESCHOT, Inleiding tot de studie van de woonhuizen te Gent ..., p. 113. 


\section{JELLE MOENS}

1904 stelde architect Ernest Van Hamme vast dat de doorbrekingen op de eerste verdieping, die tot dan als vensteropening waren ingevuld, in oorsprong eveneens deuropeningen waren ${ }^{36}$.

In een jongere bouwfase werd een achterbouw tegen het voorhuis opgetrokken wat tot gevolg had dat de achtergevel een binnenmuur werd. De doorbrekingen werden opgevuld met baksteen- of breuksteenmetselwerk of waar nodig opengebroken om een doorgang te creëren tussen de beide structuren. Op de eerste verdieping bleef evenwel één vensteropening in haar oorspronkelijke toestand bewaard. In de dikte van het muurwerk, dat oploopt tot zo'n 79,5 centimeter, zit een schouderboogvormige vensteropening die aan de buitenzijde wordt afgeschermd door slanke smeedijzeren dievenstaven (afb. 5). In de beide dagkanten zitten telkens twee smeedijzeren duimen waarop luiken konden draaien. De vensteropeningen in de voormalige achtergevel dragen aan de bovenzijde een vlakke houten afdekking waarvoor een vlak gehouwen latei in breuksteen werd geplaatst. Boven elke latei wordt de neerwaartse druk opgevangen door een ontlastingsboog in Doornikse steen.

In de zijgevels, die beide vier traveeën tellen, werd eveneens per travee en per bouwlaag in een doorbreking voorzien. In hun huidige staat gaat het om segmentboogvormige vensteropeningen maar het staat vast dat deze in oorsprong een schouderboogvormige afdekking hadden. Voor alle doorbrekingen in het voorhuis kan gesteld worden dat de overspanningen aan de binnenzijde worden opgevangen met een segmentboog.

Om de draagstructuur in het pand te integreren werden in de beide langsgevels van het voorhuis kraagstenen ingewerkt. Deze omvangrijke steunelementen zijn vervaardigd uit Doornikse steen in een kwartbolprofiel. In de voorgevel zitten tweeëntwintig kraagstenen, terwijl er in de achtergevel een twaalftal werden opgemerkt. In het vroegste stadium, toen er van een goot nog geen sprake was, lag er naar alle waarschijnlijkheid een overkragende stenen lijst op deze steunelementen die ervoor zorgde dat het regenwater op voldoende afstand van het muurvlak werd weggespoeld. In de achtergevel zitten boven de kraagstenen nog sporen van afgekapte platen in Doornikse steen.

\section{... houten skelet}

Om de gestrekte rechthoekige ruimte te overbruggen werden houten standvinken halverwege de diepte van het voorhuis geplaatst. Deze standvinken hebben

36 Het valt nauwelijks te achterhalen of deze bevindingen gegrond waren aangezien er geen schriftelijke neerslag bewaard bleef van de concrete vaststellingen van de architect. 


\section{DE SPIJKER AAN DE PENSMARKT}

een vierkante doorsnede met afgeschuinde hoeken en vertonen, in een wisselend aantal zijvlakken, over hun hele lengte gleuven die gemiddeld twee centimeter breed zijn. In sommige gevallen verbreden de gleuven tot rechthoekige uitgehouwen structuren ( $14 \mathrm{~cm}$ hoog $\times 4 \mathrm{~cm}$ breed $\times 8 \mathrm{~cm}$ diep) (afb. 6).

Deze standvinken dragen, samen met de houten strijkbalken aan de langsmuren, de vlakke balkenzoldering. Op de standvinken rust immers de samengestelde onderslagbalk waarop haaks, en vrij dicht bij elkaar, de dwarsbalken werden geplaatst (afb. 7). Aan de langsmuren worden de dwarsbalken opgevangen door de strijkbalken die op hun beurt rusten op een houten verdeelbalkje dat wordt ondersteund door twee kraagstenen. Aan de binnenzijde van de voormalige achtergevel (eerste verdieping) wordt elke doorbreking namelijk langs weerszijden geflankeerd door een kraagsteen met kwartbolprofiel in breuksteen.

De houten structuur in het voorhuis wordt bekroond door een sporenkap met keperspanten. Elk spant bestaat uit twee schuin opstaande spanten of sporen die met elkaar verbonden zijn door middel van een hanenbalk, en dit op twee niveaus. Onder elke hanenbalk ligt in de breedte van de constructie een onderslagbalk ter ondersteuning. De spanten zijn onderling niet verbonden, tenzij door de kepers, want er is geen nokbalk (afb. 8). De nokverbinding verschijnt pas op het einde van de veertiende eeuw ${ }^{37}$, wat maakt dat deze kapconstructie als ouder te dateren valt (afb. 9).

Toen het voorhuis nog een commerciële functie bezat, in het bijzonder als graanstapelhuis, moet het zadeldak zeker en vast een waterdichte dakbedekking gedragen hebben die voorkwam dat het gestockeerde graan vochtig en dus waardeloos kon worden. Naar alle waarschijnlijkheid werden hiertoe gebakken daktegels gebruikt die tot een grotere belasting van de kapconstructie leidden. Om hieraan te verhelpen werden op de zoldervloer standvinken als centrale steun geplaatst.

\section{Het gebruik als stapelhuis}

Een sluitend antwoord formuleren op de vraag hoe de Spijker concreet functioneerde als stapelhuis is onmogelijk. Er bleef niet de minste beschrijving of vluchtige herinnering bewaard in de bronnen. Wat rest is een gebouw dat bewoners zag komen en gaan, dat werd aangekleed volgens de eigentijdse mode of werd verminkt volgens de persoonlijke smaak. Deze beperking indachtig is het niet mogelijk dé historische waarheid in al haar details neer te

37 P. HOFFSUMMER, Bouwhout en dakconstructies: de dendrochronologie ten dienste van de archeologie en de datering van monumenten, Gent, 1997, s.p. 


\section{JELLE MOENS}

schrijven. Aan de hand van een analyse van de bouwsporen kan wel geprobeerd worden een samenhangend beeld te reconstrueren en bepaalde elementen betekenisvol te duiden.

Het streven naar een efficiënte werking vormde het centrale uitgangspunt bij de inrichting van het pand. Het basisvolume in Doornikse steen werd ingevuld met een houten structuur die was afgestemd op de eisen die aan het stapelhuis werden opgelegd. Het aangevoerde graan bleef doorgaans acht tot veertien dagen liggen waarna het op de markt werd gebracht. Vermits het tijdstip en de hoeveelheid graan gebonden waren aan de schepen die aanmeerden in de Leiehaven, zat er verloop op de activiteiten zodat de inrichting van het stapelhuis een zekere flexibiliteit diende te garanderen. Zo moeten de talrijke gleuven en uitgehouwen openingen in de standvinken en onderslagbalken bekeken worden in het licht van de compartimentering binnen het uitgestrekte rechthoekige grondplan. Hierin pasten vermoedelijk schotten, al dan niet vastgezet met een dwarsbalk waarvoor een uitsparing werd uitgehouwen, die toelieten een aangepaste ruimte af te scheiden. Mogelijk bestonden deze schotten uit houten planken die met een visbekprofiel in elkaar pasten opdat ze een verhoogde weerstand konden bieden aan het uitgestorte graan. Graan dat werd uitgestort op een plankenvloer, heeft immers geen puntgewicht maar verspreidt zich onmiddellijk over het hele vloeroppervlak. Met het volstouwen van de compartimenten was er dus niet alleen een neerwaartse krachtwerking gemoeid maar ook een zijdelingse druk. Het gebruik van muurankers, waarbij de veer trekt op een vernageling en op een bijkomende kram, mag als een technisch hulpmiddel beschouwd worden om aan deze zijwaartse krachten weerwerk te bieden. Ook de vloeren werden aan deze specifieke situatie aangepast. Zoals in situ vast te stellen is door de windscheuren in het plafond op de eerste verdieping (huidige Pensmarkt 7-9) liggen er twee plankenvloeren kruiselings over elkaar. Deze techniek liet toe dunne planken te gebruiken die, in geval er zich windscheuren zouden voordoen, konden garanderen dat er nog een intact vloerniveau behouden bleef dat de doorsijpeling kon verhinderen. Om het gewicht van heel de vloer te ondervangen, werden de dwarsbalken vrij dicht naast elkaar geplaatst zodat er telkens maar een kleine ruimte moest overbrugd worden.

$\mathrm{Bij}$ het toetsen van dit constructieconcept aan de situatie ter plaatse werd duidelijk dat een aantal standvinken ontbreekt. De uitgehakte, rechthoekige openingen aan de onderzijde van de onderslagbalken boden echter een aanwijzing voor hun thans verdwenen positie. Op de eerste verdieping stonden zeven standvinken, een reeks die vermoedelijk werd herhaald op de tweede verdieping maar die nu niet meer compleet is (afb. 10 en 11).

Zoals blijkt uit de illustraties, lagen er op de verdiepingen twee grote stapelruimtes achter elkaar die verder konden onderverdeeld worden in kleinere compartimenten. Met het oog op de circulatie kan op de eerste verdieping 


\section{DE SPIJKER AAN DE PENSMARKT}

gewezen worden op de vijfde travee, die mogelijk ook op de tweede verdieping werd benut als circulatieas, al werd hierover geen uitsluitsel verkregen. Vermoedelijk liep er op beide verdiepingen nog een gangpad parallel aan de achtergevel. Deze gang maakte het lossen en laden in de achterste compartimenten mogelijk en kon verlicht worden door middel van de vele doorbrekingen in de achtergevel, die desgewenst werden afgesloten met luiken.

In de Spijker werden de graanzakken denkelijk binnengehaald doorheen de deuropeningen in de voorgevel. Om de zakken tot op de eerste verdieping te krijgen, kon mogelijk een beroep gedaan worden op meerdere hengsels. Met dit hijssysteem kon men een vracht omhoog takelen, waarna het graan in het bestemde compartiment werd uitgestort. Waar precies de hijsbalken of -haken in het gevelvlak ingewerkt zaten, valt niet meer te achterhalen. Het dient opgemerkt dat het lossen van de graanzakken op de zolderverdieping met een dergelijk systeem niet mogelijk was. Hiervoor kan eerder gedacht worden aan een vorm van interne circulatie met behulp van een takel of aan een extern houten laad- en lossysteem aan de buitenzijde van de voorgevel.

\section{Aanbouw van een bakstenen vierkantstructuur}

Het voorhuis van de Spijker was initieel een zelfstandig bouwwerk dat geleidelijk aan werd omsloten met bebouwing tot het zijn huidige context bereikt had. Tegen de achtergevel van het voorhuis werd op een niet nader bekend ogenblik een bakstenen vierkantstructuur aangebouwd (afb. 12). Op de huidige plattegrond van de Spijker omvat de achterbouw in zijn totaliteit drie bouwvolumes, waarbij het meest zuidelijke volume als de vierkantstructuur kan geïnterpreteerd worden. Deze onderscheidt zich van de rest van de achterbouw door zijn opmerkelijke muurdikte, zowel wat betreft de huidige binnenmuur als de achtermuur. Ook het verschil in vensteropeningen op de eerste en tweede verdieping trekt de aandacht, al zijn deze bouwsporen sterker onderhevig aan eventuele verbouwingen.

Binnen deze vierkantstructuur werden diverse interieurelementen aangetroffen. Zo zit in de zuidelijke zijmuur op de begane grond een grote segmentboogvormige doorbreking waarbij in de diepte van het muurwerk twee verdiepte vensterbanken staan (afb. 13). Tussen beide banken, die volledig vervaardigd zijn in Doornikse steen, ligt een verdiept fragment van een tegelvloer. De roodgebakken tegels $(21 \times 21 \mathrm{~cm})$ werden nagenoeg zonder enig voegwerk geplaatst.

In hetzelfde muurvlak zit naast de banken een nis in mijterboogvorm uitgespaard, die vlakbij wordt herhaald in de achtermuur. Een interpretatie als kaarsnis werpt de vraag op waarom elders geen soortgelijke nissen werden aangetroffen. Meer voor de hand ligt het vermoeden dat de nissen een vorm 


\section{JELLE MOENS}

van eigendomsaanduiding waren om betwisting bij gemene muren te voorkomen $^{38}$. Op de eerste verdieping zitten in de zuidelijke zijmuur twee dichtgemetselde vensteropeningen. Onder de vensteropening nabij de achtermuur werden eveneens twee verdiepte vensterbanken in Doornikse steen opgemerkt. Bij het in onbruik raken van de vensterbanken werd de beenruimte opgevuld met baksteenmetselwerk en werd er een breukstenen plaat op gelegd die parallel loopt met de afdekplaten van de zitbanken. In een jongere fase werd besloten de vensteropening te verkleinen waartoe een nieuwe, kleinere onderdorpel werd aangebracht boven de reeds aanwezige dorpel. Al deze elementen wijzen op een leeffunctie binnen dit woonvolume. De vraag of er aan de bakstenen vierkantstructuur een oudere, houten woontoren vooraf ging, kon niet beantwoord worden.

\section{Het voltooien van de achterbouw}

Na het optrekken van de vierkantstructuur werden de overige twee volumes van de achterbouw tegen het voorhuis aangebouwd. Het feit dat alle muren in baksteen zijn opgetrokken, wijst op een volgende stap in de evolutie van het materiaalgebruik: het vertrouwen in de baksteen als een volwaardig bouwmateriaal manifesteert zich. De doorbraak van de baksteenbouw in de stad Gent valt grosso modo te situeren in de veertiende eeuw ${ }^{39}$. Deze datering wordt bevestigd door een bouwspoor in de noordelijke zijmuur van de achterbouw. Op de eerste verdieping werden immers twee vensteropeningen, voorzien van dievenstaven, luikduimen en opleggaten, dichtgemetst naar aanleiding van de bouw van het naastgelegen Groot Vleeshuis (1407-1419).

In de achterbouw werd evenwel nog beperkt gebruik gemaakt van Doornikse steen. In de nabijheid van de achtermuur werden breukstenen dorpels als verankering ingewerkt en ook de kraagstenen die deel uitmaken van de draagstructuur zijn vervaardigd uit Doornikse steen. Deze laatste zitten in de binnenmuren ingewerkt en dragen een uitkragende breukstenen lijst waarop een houten strijkbalk rust, die op zijn beurt de zware dwarsbalken draagt (afb. 14). Aangezien hout niet goed bestand is tegen drukkracht vangt de stenen lijst de druk op. De strijkbalk zorgt in dit geval voor de verdeling van de last zodat de stenen lijst meer gelijkmatig weerstand kan bieden.

Per verdieping staan alle ruimtes met elkaar in verbinding; alle doorgangen liggen op één lijn vlak naast de voormalige buitengevel van het voorhuis. Elke

38 M. C. LALEMAN, P. RAVESCHOT, Inleiding tot de studie van de woonhuizen te Gent ..., p. 166.

39 M. C. LALEMAN, P. RAVESCHOT, Inleiding tot de studie van de woonhuizen te Gent ..., p. 145. 


\section{DE SPIJKER AAN DE PENSMARKT}

doorgang wordt afgedekt door een dubbele rollaag die een segmentboog omschrijft. De negblokken in Doornikse steen flankeren telkens én zijde van de doorgang.

\section{Een analyse van de achterbouw}

In de Steneninventaris staan onder het adres 'Pensmarkt 3-9' twee constructies vermeld ${ }^{40}$. De eerste constructie (S 130) valt samen met het voorhuis van de huidige Spijker dat is opgetrokken in Doornikse steen. Een tweede constructie (S 131) ligt parallel aan de eerste in noordwestelijke richting op ruim 1,70 meter afstand. Van deze smalle constructie, die mogelijk even breed was als het voorhuis, bleef enkel de onderste bouwlaag in Doornikse steen onder het huidige vloerniveau bewaard ${ }^{41}$ (afb. 15). Bij een latere verbouwing in baksteen $(26 / 28 \times 13 \times 5,5 / 6 \mathrm{~cm})$ werd het volume verbonden met het voorhuis en vormde het vanaf dan én geheel ${ }^{42}$. De doorbrekingen in de noordelijke zijgevel werden weggewerkt met Doornikse steen, wat erop duidt dat deze gevel vrij stond voor de bouw van het Groot Vleeshuis. Deze bouwfase is dus ouder dan het begin van de vijftiende eeuw, hetgeen bevestigd wordt door het feit dat het dak van het Groot Vleeshuis op deze bakstenen constructie rust. In de Spijker is dit muurwerk niet zichtbaar vermits het onder een bepleistering zit.

Welke functie de achterliggende constructie in oorsprong vervulde, is niet bekend. Er zijn echter enkele vermoedens die in relatie tot de structuur S 131 kunnen geformuleerd worden. In welk materiaal de bovenliggende bouwlagen in oorsprong waren opgetrokken, is niet geweten maar gesteld dat louter de voeting van het gebouw in Doornikse steen was opgebouwd met daarboven een houten constructie, kan gedacht worden aan het vroegste Vleeshuis dat in een jongere fase werd verlaten voor een nieuw en bovenal ruimer gebouw dat ernaast werd opgetrokken. Een andere mogelijkheid luidt dat een eventuele houten constructie ter hoogte van S 131 kan geïdentificeerd worden als de houten spijker die eigendom was van het hospitaal Sint-Jan-ten-Dulle.

In de literatuur wordt soms verwezen naar de 'oude' spijker als voorloper van de Spijker op de Hooiaard ${ }^{43}$, die volgens sommige auteurs in hout was opge-

40 M. C. LALEMAN, P. RAVESCHOT, Inleiding tot de studie van de woonhuizen te Gent ..., pp. 113-114.

41 M. C. LALEMAN, P. RAVESCHOT, Vondstenmelding Groentenmarkt, Vleeshuis, IN: Stadsarcheologie. Bodem en monument in Gent, 1989, XIII, 4, p. 17.

42 P. RAVESCHOT, Vondstenmelding Graslei 1-3, Pensmarkt 3-9, IN: Stadsarcheologie. Bodem en monument in Gent, 1992, XVI, 3, p. 40.

43 F. DE POTTER, Gent van den oudsten tyd tot heden. Geschiedkundige beschrijving der stad, Gent, 1882-1901, volume 2.2., p. 464. 


\section{JELLE MOENS}

trokken $^{44}$. Deze constructie behoorde toe aan het hospitaal van Sint-Jan-tenDulle, een verzorgingstehuis voor geesteszieken gelegen aan de huidige Vlasmark $\mathrm{t}^{45}$. Frans De Potter meende in deze constructie een eerste spijker te herkennen, gelegen nabij de Veebrug ${ }^{46}$. Volgens hem werd na de afbraak van de oude spijker in 1321-1322 een nieuwe, tweede spijker ingericht in het "nog bestaande oude gebouw". Een meer recente studie toont aan dat dit graanstapelhuis inderdaad kan gesitueerd worden nabij de Veebrug, meer bepaald aan de zijde van de Sint-Michielsbrug en dus ter hoogte van de huidige Graslei ${ }^{47}$. Wanneer omstreeks 1321-1322 de stadsmagistraat besluit om op de desbetreffende plaats een aard of aanlegplaats te maken, werd de onteigening en de sloop van de oude spijker ingezet. In de stadsrekeningen werden de slopingskosten genoteerd vanden ouden Tspikere te brekene ${ }^{48}$. Het hospitaal kreeg als vergoeding voor het geleden verlies de opbrengst van de sluizen aan het Paddegat, de Rode Torenbrug en de Torhoutbrug 49 . Uit het voornoemde onderzoek bleek nergens een band te bestaan tussen de spijker van het voornoemde hospitaal en de Spijker aan de Pensmarkt. In het archiefonderzoek dat aan deze studie voorafging, werd evenmin een verwijzing naar het hospitaal van Sint-Jan-ten-Dulle of naar de oude spijker aangetroffen.

Een kritische opmerking die bij de voorgaande beschrijving kan gemaakt worden, is de vraag of de oude spijker en de houten spijker wel één en hetzelfde gebouw zijn. Het lijkt niet ondenkbaar dat er meer dan één stapelhuis op de Leie-oever stond. De eerste spijker stond tussen de Sint-Michielsbrug en de Veebrug, een tweede Spijker kan op de structuur S 131 geslaan hebben, waarbij de onderbouw in Doornikse steen verhinderde dat de bovenstaande houten constructie werd aangetast door opstijgend grondwater. Verder bouwend op deze hypothese, kan gesuggereerd worden dat het houten stapelhuis toebehoorde aan het Gasthuis Onze-Lieve-Vrouw ter Lazarije maar op een gegeven ogenblik niet langer meer geschikt werd bevonden en werd verlaten. De

44 J. DECAVELE, De oude Leiehaven te Gent. Het romaans stapelhuis, IN: Toerisme Oost-Vlaanderen, 1973, XXII, 4, p. 59, K. DE VINCK, De metamorfosen van een stadsgezicht ..., p. 32, W. VLERICK, De nieuwe Leie, IN: Langs de Gentse waterwegen, Gent, 1973, pp. 4-6, Het Spijker ou 1' Epier, IN: Palmarès, 1969, XI, 5, p. 7.

45 L. ELAUT, Het leven van de Gentse ziekenhuizen vanaf hun ontstaan tot op heden, Gent, 1976, p. 31.

46 F. DE POTTER, Gent van den oudsten tyd tot heden ..., volume 2.2., p. 464.

47 M. C. LALEMAN, D. LIEVOIS, De Grasbrug, IN: M. C. LALEMAN (red.), 7 bruggen. Historiek en restauratie van zeven Gentse Leiebruggen, Gent, 1987, p. 62 .

$48 \mathrm{~J}$. VUYLSTEKE, Gentsche stads- en baljuwsrekeningen, 1280-1336, Gent, 1900, deel 1, p. 190.

49 SAG., Oud Archief, Reeks 93 (Cartulaire-Inventaires, Chartes-Plans), nr. 1, Register 1 (Ouden Gheluwen bouck), f. $120 \mathrm{v}$. 


\section{DE SPIJKER AAN DE PENSMARKT}

graanstapel verhuisde vervolgens naar het grote, stenen gebouw dat zich voor de houten constructie uitstrekte.

\section{Van stapelhuis tot woonhuis}

In januari 1492 besloot het Gasthuis Onze-Lieve-Vrouw ter Lazarije af te zien van de Spijker ${ }^{50}$. Voor de schepenen van de Keure werd een akte opgesteld waarin Barbele tSaeghers als meesteres van het Gasthuis, samen met de bevoegde voogden, de Spijker overdroeg aan priester Janne vander Meulene. Deze laatste maakte aanspraak op drie vierendelen terwijl het vierde deel toekwam aan zijn minderjarige nichtje Merkine vanden Zompele, over wie hij de voogdij waarnam. De koopsom bedroeg 16 ponden groten Vlaamse munt maar werd Janne vander Meulene kwijtgescholden door het Gasthuis. Op deze manier wist het Gasthuis zich nog van enige inspraak te verzekeren en kon ze de nieuwe eigenaar verbieden de Spijker te verkopen of over te laten aan een ander klooster, nering of gilde. De Spijker mocht evenmin in dode hand terecht komen. Dit zou immers betekenen dat het vermogen van Janne vander Meulene werd overgedragen aan een derde persoon die de zaken behartigde volgens de wens van de opdrachtgever en zo de rechtstreekse beschikkingsmacht van de familieleden, in het bijzonder van Merkine vanden Zompele, buitenspel kon zetten.

Twee decennia later was Margaretha vanden Zompele, zoals haar volwaardige naam luidde, gehuwd met Philips de Stoppelaere die als vroegste eigenaar van de Spijker voorkomt in de cijnsboeken van het Gasthuis Onze-LieveVrouw ter Lazarije ${ }^{51}$. Jaarlijks betaalde hij op kerstavond 20 schelling groten, een gebruik dat door zijn nageslacht zou worden voortgezet. Het omvangrijke pand aan de Hooiaard was omstreeks 1570 onderverdeeld in diverse woningen ${ }^{52}$. Voor de Spijker had dit hergebruik gevolgen met het oog op de interne structuur. Om diverse woningen te integreren in het pand was er allereerst nood aan scheidingswanden tussen de wooneenheden. Over de precieze indeling, noch over de gebruikte materialen en technieken zijn gegevens bekend. Werd er gebruik gemaakt van de schotten van het stapelhuis? Of werd er, omwille van het brandgevaar inherent aan het houtgebruik, eerder de voorkeur gegeven aan bakstenen muren of aan opvullingen met vitswerk die werden bestreken met pleister? Hoe dan ook was er per woning normaliter een

50 SAG., Oud Archief, Reeks 301 (Jaarregisters van de Keure. Acten en contracten), nr. 62, Register 1492-1494, deel 1492-1493, f. 45 r.

51 RAG., Oud Archief, Rijke Gasthuis (Cijnsboeken van gronden te Gent), nr. 182 (1523-1602), f. $143 \mathrm{v}$.

52 SAG., Oud Archief, Reeks 330 ((Oude) Staeten van goeden en "Acten en contracten"), nr. 88 (MF 130), Register 1570-1571, f. 178 r. 


\section{JELLE MOENS}

haard voorzien als warmtebron en als kookgelegenheid zodat een minimum aan comfort gegarandeerd was.

In 1650 huurden Hendrick Ronse, Jooris van Haerde en de weduwe van Daniel den Panne een woning in de Spijker ${ }^{53}$, die vijf jaar later nog steeds bekend stond als een huyse, dry woonsteden wesende ${ }^{54}$. De discussie rond de erfenis van Philips de Stoppelaere zou deze situatie echter spoedig wijzigen. Nog in hetzelfde jaar 1655 werd de Spijker opgedeeld in twee kavels: kavel A was aan de straatzijde 21 voeten (5,78 meter) breed met 't cleen huyseke daeranne ghemaeckt wesende eene braderie, kavel B besloeg een breedte van 31 voeten $(8,53 \text { meter })^{55}$ (afb. 16). Enkele decennia later slaagde Jan Baptist de Stoppelaere, heer van Portes, erin om de Spijker opnieuw in én hand te herenigen. Bij zijn overlijden erfde zijn douairière of adellijke weduwe, Helena Theresa van Nieuwmunster, alle commeren ende baeten, inclusief de Spijker. De weduwe overleefde eveneens haar tweede echtgenoot, Nicolaijs Caré, maar bleef niet bij de pakken zitten en huwde voor een derde maal, nu met Jan van de Kerchove, heer van Vau(l)x en oud-schepen van de Keure (1678) van de stad Gent.

\section{De 18de eeuw: twee woningen, twee eigenaars}

Bij aanvang van de achttiende eeuw waren in de Spijker twee woningen ingericht, die werden verhuurd aan Marcus Van Belle (woning aan de zijde van de Grasbrug) en aan een zekere N. Vermeulene (woning aan de zijde van het Groot Vleeshuis) ${ }^{56}$. De echtelieden Van de Kerchove-van Nieuwmunster overleden kort na elkaar, waarop de erfgenamen van Helena Theresa van Nieuwmunster besloten de Spijker te verkopen ${ }^{57}$. Op 15 oktober 1709 werd de verkoopsakte ondertekend voor de notarissen Serlippens en De Rynck ${ }^{58}$ : Pieter de Maeght, tavernier van beroep, verwierf het deel op den candt naest het voornoemde vleeschuys van vooren ter straete tot vier veynsters daerinne

53 SAG., Oud Archief, Reeks 153/2 (Quohieren van prijsijen van het huysgeld), nr. 99, Schatting van de wijk van kapitein Dormael, opgemaakt door Maximiliaen Reynacx, 1650, s.f., 'In den Hoyaert'.

54 SAG., Oud Archief, Rijke Gasthuis (Cijnsboeken van gronden te Gent), nr. B 1319 (1698-1796), f. 458 r.

55 RAG., Oud Archief, Rijke Gasthuis (Cijnsboeken van gronden te Gent), nr. 184 (1545-1695), f. 459 r.

56 SAG., Oud Archief, Reeks 153/1 (Registres intitulés. Huisgeld), nr. 122 (MF 30), f. 49 r-v.

57 Jan Van de Kerchove overleed kinderloos op 20 augustus 1706. Zijn echtgenote overleed in oktober 1708. UIT: M. DE VEGIANO, Nobiliaire des Pays-Bas et du Comté de Bourgogne, p. 1120.

58 RAG., Oud Archief, Notariaat (G. Serlippens), nr. 1142282 (MF), f. 309 r. 


\section{DE SPIJKER AAN DE PENSMARKT}

begrepen de deure en Jan Lanneaux, een meester chirugien, kocht de woning aan de zijde van de Graslei. De scheidingsmuur tussen de beide woningen stond en staat nog steeds in het midden van de penant tussen de vijfde en de zesde travee (afb. 17). Deze binnenmuur, die 22 centimeter dik was, werd op een rechte lijn doorgetrokken tot aan de binnenzijde van de voormalige achtergevel van het voorhuis ${ }^{59}$. In de achterbouw sloot de nieuwe scheidingsmuur aan op de bestaande oude bakstenen muur. In het verkoopscontract werd Jan Lanneaux verantwoordelijk gesteld voor het onderhoud van de goot en de afvoerbuis waarin het hemelwater van de beide woningen werd opgevangen.

Toen de verkoop werd afgesloten, huurde Guillaume Smeeckens nog een woning in het voorhuis van de Spijker ${ }^{60}$. Zijn huur zou pas drie jaar later vervallen op 24 januari 1712. De nieuwe scheidingsmuur zou ook zijn woonruimte, die zich beperkte tot de begane grond en de eerste verdieping, doorsnijden. Er werd besloten het huurcontract niet te verbreken, zodat de scheidingsmuur pas na 1712 definitief in steen kon opgetrokken worden. Tot die tijd moest de scheiding op de eerste verdieping in hout worden uitgevoerd. Pieter de Maeght werd verplicht afstand te nemen van het venster op de begane grond in de zesde travee, in afwachting van het aflopen van het huurcontract.

\section{De woning aan de zijde van de Grasbrug}

Jan Lanneaux liet bij zijn overlijden de woning na aan zijn broer Laureyns, die ze op zijn beurt verhuurde aan Laureyns de Paepe ${ }^{61}$. Deze meester chirurgien ende steensnyder kocht de woning omstreeks 1750 van Lanneaux over en deelde het huis op in twee eenheden: hijzelf bewoonde de zijde aan de Grasbrug, Jacobus d'Huyvetter, een collega-meester chirurgien ende accoucheur (verloskundige), woonde in de andere zijde. In 1769 werden beide woningen eigendom van Jan Baptist de Smet, in wiens bezit ze bleven tot bij zijn overlijden in november $1777^{62}$. Een groot deel van het woonhuis werd verhuurd zodat de feitelijke eigenaar slechts over een klein woonhuis beschikte. Toen op 7 mei 1778 schatter Jan Baptist Teirlijnck de inventaris van het sterfhuis van Jan Baptist de Smet kwam optekenen, moest hij alleszins niet veel kamers doorlopen ${ }^{63}$. Hij zakte van het eerste opperste (zolderverdieping)

$59 \quad$ RAG., Oud Archief, Notariaat (G. Serlippens), nr. 1142282 (MF), f. 309.

60 RAG., Oud Archief, Rijke Gasthuis (Cijnsboeken van gronden te Gent), nr. B 1319 (1698-1796), f. 458 bis v.

61 RAG., Oud Archief, Rijke Gasthuis (Cijnsboeken van gronden te Gent), nr. B 1319 (1698-1796), losse aktes.

62 SAG., Oud Archief, Reeks 332 (Minuten van Staten van Goed), nr. 764 (5), 3 ougste 1778-4 november 1778 .

63 SAG., Oud Archief, Reeks 332 (Minuten van Staten van Goed), nr. 764 (5), 3 ougste 1778-4 november 1778. 


\section{JELLE MOENS}

af naar het tweede opperste (tweede verdieping) en liep vervolgens door naar de voor caemere (eerste verdieping). Op de begane grond lag achteraan een keuken en vooraan een winkelruimte, waarmee naar alle waarschijnlijkheid een herberg bedoeld werd aangezien er naast een toog ook enkele vaten bier en een vat jenever werden vermeld. In de Oostenrijkse registers van het huisgeld, die de periode van 1796 tot 1800 beslaan, staat de weduwe van Jan (Baptist) de Smet nog steeds als eigenares van het huis bekend, Jacobus d'Huyvetter nam als huurder de hele woning in gebruik ${ }^{64}$.

De sporen van achttiende-eeuwse bouwactiviteiten zijn in deze woning eerder schaars. De haard in rode papensteen $(17 \times 8 \times 4 \mathrm{~cm}$ ) op de begane grond (achterhuis, Pensmarkt 3-5) werd vermoedelijk in de achttiende eeuw gebouwd ter vervanging van een bredere haard. De huidige haard wordt immers voorafgegaan door een raveelconstructie die op de strijkbalk verder reikt dan de haardboezem. Op de tweede verdieping (voorhuis, Pensmarkt 3-5) staat tegen de scheidingsmuur een trap met kwart die naar links draait en toegang verleent tot de zolderverdieping. De balusters bestaan uit slanke, gedraaide spijlen die onderaan verdikken in combinatie met blokjes ter hoogte van de leuning en de trapboom (afb. 18). De trappaal heeft een vierkante doorsnede en wordt bekroond door een afgeknotte peervorm met vier facetten.

In de tweede helft van de achttiende eeuw werd de blauw hardstenen toegangstrap tot de woning aan de zijde van de Grasbrug vernieuwd. In de onderste trede die naar de voordeur leidt, werd het steenhouwersmerk NPN aangetroffen. Deze lettercode verwijst naar de identiteit van meester-steenhouwer Nicolas Paternotte, die werkzaam was in de gemeente Arquennes (Henegouwen) ${ }^{65}$.

\section{De woning aan de zijde van het Groot Vleeshuis}

In het voorjaar van $1726 \mathrm{kwam}$ Pieter de Maeght te overlijden66. Zijn weduwe, Anna Deijnoot, schonk het huis met de gehele inboedel als donatio inter vivos aan haar zoon Jacobus de Maeght die de zaak verder uitbaatte ${ }^{67}$. Na het overlijden van Jacobus omstreeks 1741 stond zijn weduwe, tevens moeder van

64 SAG., Oud Archief, Reeks $153 / 1$ (Registres Intitulés. Huisgeld), nr. 195, Index-Registre marque " $Q$ ", f. 31 r.

65 M. C. LALEMAN, Steenhouwer Nicolas Paternotte, IN: Stadsarcheologie. Bodem en monument in Gent, 1989, XIII, 1, p. 44.

66 RAG., Oud Archief, Rijke Gasthuis (Cijnsboeken van gronden te Gent), nr. B 1319 (1698-1796), f. 458 tris r.

67 RAG., Oud Archief, Notariaat (J. B. De Stobbeleer), nr. 1140065 (MF), f. 335 r. 
zes kinderen, er alleen voor in de herberg 68 . Joanne Lantheere besloot de woning te verkopen en in maart 1766 stelde notaris Millecam een verkoopsakte op waaruit blijkt dat Pieter Geeraerts voortaan de nieuwe eigenaar zou zijn 69 . Ook Geeraerts hield de herbergtraditie in ere en liet bij zijn overlijden in 1784 de zaak over aan zijn oudste zoon en naamgenoot Pieter. De nieuwe zaakvoerder deelde de woning met zijn jongere broer Joannes Franciscus Geeraerts en diens gezin ${ }^{70}$. Aldus bleef de woning tot het einde van de achttiende eeuw in bezit van de erfgenamen van Pieter Geeraerts (vader) ${ }^{71}$.

De achttiende-eeuwse verfraaiingscampagne werd vermoedelijk pas opgestart na het aflopen van het huurcontract van Guillaume Smeeckens in 1712. Eenmaal Pieter de Maeght over zijn volledige woonhuis kon beschikken, werden enkele ingrepen verricht volgens de toen heersende mode. Zo werd op de begane grond (voorhuis, Pensmarkt 7-9), in de hoek tussen de nieuwe scheidingsmuur en de langse binnenmuur, een eikenhouten slingertrap geplaatst die doorliep tot op de zolderverdieping (afb. 19). De ingesneden leuning omschrijft een ovaalvormig schalmgat en wordt gedragen door slanke, gedraaide spijlen die getooid zijn met blokjes, vergelijkbaar met de balusters van de trap met kwart in de naastgelegen woning. De buitenboom van de trap werd op de eerste verdieping bepleisterd, zoals blijkt uit sporen van rinkellatjes. Deze ingreep droeg, naast het decoratieve karakter, bij aan de brandveiligheid.

Op de eerste verdieping werd in de voorkamer (voorhuis, Pensmarkt 7-9) tegen de noordelijke zijmuur een bakstenen haard $(21 / 23 \times 11 / 13 \times 5,5 / 5 \mathrm{~cm})$ geplaatst. De haardboezem en de haardmantel vertonen afgeschuinde zijden, een vormgeving die in gebruik was in de eerste helft van de achttiende eeuw. In de haardmond werden zowel de stookwand als de haardwangen bezet met vuurvaste steentjes. Eenzelfde vormgeving en bezetting met vuurvaste steentjes werd ook aangetroffen bij de bakstenen haard $(17 \times 9 \times 4,5 \mathrm{~cm})$ in de achterkamer (achterbouw, Pensmarkt 7-9), die centraal tegen de zijmuur staat. Beide haarden waren, volgens het gangbare gebruik, met stucwerk bepleisterd en beschilderd. Het gemetste haardgewelf dat de haarden voorafgaat, werd mee bepleisterd en vormde de overgang naar het stucwerkplafond. Op de tweede verdieping stond eveneens een haard in de voorkamer, al is daar op een roetspoor en enkele bakstenen na thans niets meer van te merken. In de

68 RAG., Oud Archief, Rijke Gasthuis (Cijnboeken van gronden te Gent), nr. B 1319 (1698-1796), f. 458 tris r.

69 SAG., Oud Archief, Reeks 332 (Minuten van Staten van Goed), nr. 800 (30), 28 april $1785-20$ juny 1785 .

70 SAG., Oud Archief, Reeks 332 (Minuten van Staten van Goed), nr. 303, 3 september tot 29 december 1792.

71 SAG., Oud Archief, Reeks 153/1 (Registres Intitulés. Huisgeld), nr. 195, Index-Registre marqué " $Q$ ", f. 31 v. 


\section{JELLE MOENS}

achterkamer (achterbouw, Pensmarkt 7-9) staat centraal tegen de zijmuur een haard met afgeschuinde zijden aan de boezem die eveneens met een stucwerkbepleistering was getooid. Aan de wanden zijn nog sporen van lijstwerk te zien die hoogstwaarschijnlijk een gestuct plafond omzoomden.

De toenmalige inrichting van de woning staat beschreven in de boedelstaat die werd opgemaakt naar aanleiding van het overlijden van Pieter Geeraerts ${ }^{72}$. Op 9 augustus 1784 betrad schatter Jacobus Vaerseele het woonhuis aan de Hooiaard. Enkele jaren later, meer bepaald op 30 [sic] februari 1792, stapte schatter Frans Paelinck dezelfde woning binnen om een inventaris van de huisraad op te maken vermits de inwonende broer van de herbergier bij zijn overlijden een minderjarige zoon naliet ${ }^{73}$. Om een idee te krijgen van de nu verdwenen kamerindeling, kunnen de beschrijvingen naast elkaar geplaatst worden.

72 SAG., Oud Archief, Reeks 332 (Minuten van Staten van Goed), nr. 800 (30), 28 april $1785-20$ juny 1785 .

73 SAG., Oud Archief, Reeks 332 (Minuten van Staten van Goed), nr. 303, Register 3 september tot 29 december 1792. 


\section{DE SPIJKER AAN DE PENSMARKT}

\begin{tabular}{|c|c|c|}
\hline & $\begin{array}{l}\text { Pieter Geeraerts } \\
(9 / 08 / 1784)\end{array}$ & $\begin{array}{l}\text { Joannes Franciscus Geeraerts } \\
(30 / 02 / 1792)\end{array}$ \\
\hline Vlieringzolder & Op het opperste & Op het opperste \\
\hline \multirow[t]{3}{*}{ Zolderverdieping } & $\begin{array}{l}\text { Op de nieuwe kamer derde } \\
\text { stagie }\end{array}$ & Op de middel solder \\
\hline & $\begin{array}{l}\text { Op het kleyn kammerken } \\
\text { op den allée }\end{array}$ & \\
\hline & Op den allée & \\
\hline \multirow[t]{4}{*}{$\begin{array}{l}\text { Tweede } \\
\text { verdieping }\end{array}$} & $\begin{array}{l}\text { Op de bovenkamers van de } \\
\text { 3de stagie }\end{array}$ & Op de tweede boven voor caemer \\
\hline & $\begin{array}{l}\text { Op de boven achter kamer } \\
\text { 2de stagie }\end{array}$ & Op de tweede boven achter caemer \\
\hline & Op den allee & Op den trap \\
\hline & & Op den tweede stagie \\
\hline \multirow{3}{*}{$\begin{array}{l}\text { Eerste } \\
\text { verdieping }\end{array}$} & Op de kamer van het mijssen & Op de eerste achter caemer \\
\hline & Op de boven voorkamer & Op de eerste boven voor caemer \\
\hline & & Op den trap \\
\hline \multirow[t]{5}{*}{ Begane grond } & In de beneden eetplaetse & In de groote voorcaemer \\
\hline & In het kleyn voorkammerken & In de cleyne voorcaemer \\
\hline & In de keuken & In de keuken \\
\hline & Op de achterplaetse & $\begin{array}{l}\text { In de kock keuken ende } \\
\text { achterploetse }\end{array}$ \\
\hline & In het schotelhuys & Op't vaute caemerken \\
\hline \multirow[t]{4}{*}{ Kelders } & In den bierkelder & In de bier en genevelkelder \\
\hline & In het voorkelderken & Beneden in het wijnkelderken \\
\hline & In het genever kelderken & \\
\hline & In het kasken op den trap & \\
\hline
\end{tabular}

\section{De 19de eeuw: de verdere opdeling van de Spijker}

Omstreeks 1800 omvatte de Spijker drie woningen. De weduwe van Jan (Baptist) de Smet bezat de woningen met het Oostenrijkse huisnummers Q 121 en Q 122 en verhuurde ze allebei aan Jacobus d'Huyvetter. De naastgelegen herberg 'Het Goude Mandeken' (Q 123) was eigendom van de erfgenamen van Pieter Geeraerts (vader). Deze situatie bleef nog enkele jaren gehandhaafd met als enige wijzigingen dat weduwe de Smet zelf haar intrek nam in nummer Q 121 en dat de huishuur van d'Huyvetter ten einde liep, waarop Angele Bral zich als nieuwe huurder aandiende ${ }^{74}$. In de Atlas Napoleon (1807) staan weduwe de Smet en Pieter Geeraerts (zoon) als eige-

74 SAG., Modern Archief, Reeks DD (Stukken betreffende het kadaster), nr. 1, Aanwijzende tabellen, 1802-1804, Bennesteeg-Zonnestraat, f. 31-33 (Q 121-Q 123). 


\section{JELLE MOENS}

naars en vruchtgebruikers van de woningen geregistreerd ${ }^{75}$. Pieternelle Therese van Holle verhuurde dus niet langer haar tweede woning en had de beide woningen voortaan ingericht als winkel. Buurman Geeraerts baatte als cabaretier nog steeds de herberg Le panier d'or uit.

In juni 1831 werd architect Guislain gevraagd om de herberg 'Het Goude Mandeken' op te delen in twee woningen ${ }^{76}$. De Spijker besloeg aldus vier perceelnummers in de kadastrale aanwijzende tabel van 183577 . De perceelnummers 15 en 15 bis die overeenstemden met de voormalige herberg, behoorden toe aan Joseph Baptiste de Contreras uit Mariakerke. De twee andere percelen, de nummers 17 en 18, waren eigendom van en bewoond door Pharailde de Smet, de jongste dochter van Jan Baptist de Smet (afb. 20). Zij verkocht haar eigendom aan de Hooiaard op een niet nader bekend tijdstip, maar alleszins voor $1852^{78}$, aan Benedict Fretin-Paquet ${ }^{79}$. Deze koopman in lakens verhuurde de beide woningen tot hij ze in 1874 verkocht aan Alfons Derreveaux, zelf woonachtig aan de Goudenleeuwplein in Gent ${ }^{80}$. Negen jaar later verwierf Derreveaux ook de twee aanpalende woningen van Therese Jacqueline Vercruysse, weduwe van de Contreras ${ }^{81}$. In 1894 werden de bezittingen van de handelaar herverdeeld: Jan Locks en Jean Verschaffelt werden de nieuwe eigenaars van de Spijker ${ }^{82}$. Twee jaar later, in 1896, verkochten ze de Spijker aan Omer Van der Stricht, een professor geneeskunde aan de Universiteit Gent ${ }^{83}$.

De vier woningen werden op de begane grond ingericht als herbergen, op de verdiepingen was er woongelegenheid voorzien. De etablissementen droegen klinkende namen als 'In de stad Leuven' (perceel 18), 'Het Engelsch paard' (perceel 17), 'In den Pensmarkt' (perceel 15 bis) en 'Het Goude Mandeken' (perceel 15).

75 UGent, Hs. 3066/I, Plan cadastral de la ville de Gand (alias Atlas Napoleon 1807), Section du Centre, première partie, dite Section C, Ilot 1, f. 3 v.

76 SAG., Reeks SCMS (Nota's straten), doos 68, Pensmarkt. Het is niet duidelijk wie architect Guislain precies is. In de Wegwijzer der stad Gent, 1828-1829 (p. 212) staan twee bouwmeesters Guislain vermeld: de ene was woonachtig in de Peperstraat, de andere in het Prinsenhof.

77 AKG., Oorspronkelijk aanwijzende tabel 208, Gent, 3e Afdeling, sectie C, $1^{\mathrm{e}}$ blad, nrs. 15,15 bis, 17 en 18 .

78 In 1852 vraagt Benedict Fretin-Paquet een bouwvergunning aan om werkzaamheden aan de achtergevel van de Spijker te laten uitvoeren. SAG., Modern Archief, Reeks G 12 (Moderne bouwvergunningen), MF 444, 1850-M-7578.

79 AKG., Kadastrale legger 212, Gent, artikels 421 en 689.

80 AKG., Kadastrale legger 212, Gent, artikels 689 en 25.

81 AKG., Kadastrale legger 212, Gent, artikels 97 en 25.

82 AKG., Kadastrale legger 212, Gent, artikel 1103.

83 AKG., Kadastrale legger 212, Gent, artikels 1103 en 1298. 


\section{DE SPIJKER AAN DE PENSMARKT}

\section{Bouwen en verbouwen}

Het voortdurend wisselen van eigenaars en huurders voor de verschillende woningen in de Spijker had tot gevolg dat aanzienlijke investeringen, op een gedeeltelijke restauratie van de voorgevel na, uitbleven. In het huidige interieur herinnert enkel een binnendeur op de eerste verdieping aan de negentiende-eeuwse inrichting. Het gaat om een deur met een drie-paneelverdeling (afb. 21), een ontwerp dat veelvuldig werd gebruikt in de empireperiode (eerste kwart van de negentiende eeuw). Vermoedelijk werd deze deur door Pieter Geeraerts aangekocht. De doorbraak van dit deurtype ging gepaard met het opkomen van een nieuw scharniertype, de $\operatorname{speun}^{84}$ (afb. 22). De speunen zitten ingewerkt in de boven- en onderregel van de deur terwijl het vaste gedeelte, onder de vorm van een plaatje, zit ingewerkt in de bovenkant van het deurkader en onderaan in de vloerplanken. In de achterkamer wordt de deurvleugel gevat in een typische halfronde deurlijst. Andere bouwsporen of afwerkingslagen werden zorgvuldig verwijderd zodat het gissen blijft hoe het interieur van deze woningen er verder uitzag.

Over de werkzaamheden aan het exterieur van de Spijker bestaan gedetailleerde omschrijvingen onder de vorm van bouwaanvragen en tekeningen (afb. 23). In het woonhuis met het Franse huisnummer 28 (perceel 15) werd een tweede deur aangebracht in de achtergevel ${ }^{85}$. Dit had tot gevolg dat in het interieur een gang werd afgescheiden opdat de andere kamers achterin zo weinig mogelijk hinder ondervonden van de circulatie. De tegelvloer (tegels van $25 \times 25 \mathrm{~cm}$ ) in deze gang werd vervaardigd uit de blauwe hardsteen Noir de Bassècle. Buurman-eigenaar Fretin Paquet richtte zich twee jaar later ook tot het stadsbestuur met een gelijkaardige vraag ${ }^{86}$. Hij wenste eveneens een tweede deur aan te brengen in de achtergevel van het aanpalende woonvolume. De werken werden hem gegund in maart 1852 maar zijn vraag om latrines te mogen plaatsen op het achterliggende erf werd evenwel afgewezen. Ook hier werd in het verlengde van de deur een gang gevormd wat tot gevolg had dat de grote achttiende-eeuwse haard in papensteen niet langer meer gebruikt werd. De opgetrokken scheidingsmuur in baksteen werd gemetst in een halfsteens verband $(23 \times 5 \mathrm{~cm})$ en had aan de zijde van het voorhuis initieel een deuropening die in een jongere fase werd dichtgemetseld.

84 G. EVERAERT, De moderne deur, 19de eeuw, IN: G. VAN DOORNE (red.), Deuren en poorten. Zeven eeuwen techniek en esthetiek, Gent, 1995, p. 126.

85 SAG., Modern Archief, Reeks G 12 (Moderne bouwvergunningen), MF 444, 1850-M-7578.

86 SAG., Modern Archief, Reeks G 12 (Moderne bouwvergunningen), MF 444, 1852-M-7579. 


\section{JELLE MOENS}

In 1893 vroeg Alfons Derreveaux, toenmalig eigenaar van de gehele Spijker, de toestemming om een deel van de voorgevel te restaureren ${ }^{87}$. De slechte staat van de breuksteen in de linker benedenhoek van de voorgevel leidde tot instortingsgevaar, waarop Derreveaux de vraag stelde of hij dit stuk mocht laten verwijderen en reconstrueren. Het plan werd goedgekeurd en de werken gingen van start in mei 1893. Tijdens de werken werd duidelijk dat het schadebeeld zich niet louter beperkte tot de begane grond en de eerste verdieping van de eerste travee en van de naastgelegen penant, ook de borstwering van de tweede verdieping werd aan een reconstructie onderworpen (afb. 24). De restauratie werd voltooid met het (her)bepleisteren en schilderen van de voorgevel, zoals te zien is op een foto van $1898^{88}$.

\section{De 20ste eeuw: een nieuwe eigenaar, een nieuwe visie: het jaar 1904}

Sinds de laatste decennia van de negentiende eeuw vormde de restauratie van de gevels van particuliere woonhuizen in de Gentse binnenstad een bijzonder aandachtspunt op de agenda van de Stedelijke Commissie voor Monumenten en Stadsgezichten. Op voorspraak van architect Joseph De Waele werd besloten een inventaris op te stellen van alle bouwwerken die, ongeacht hun stijlkenmerken, ook maar enige interesse naar behoud toe opwekten ${ }^{89}$. Hiertoe werd een subcommissie samengesteld waarin naast architect De Waele ook Prosper Claeys en Charles Lacquet zetelden. Binnen de maand had de subcommissie, mits een gewijzigde samenstelling ${ }^{90}$, een lijst opgesteld die echter vrij omvangrijk was. De leden van de Stedelijke Commissie stapten daarom het parcours af en passeerden onder meer aan de Pensmarkt waar de Spijker als façades romans, modifiés dans leurs parties intérieurs, XIIle siècle stond geregistreerd ${ }^{91}$. Toenmalig burgemeester Emile Braun werd overtuigd van de plannen en stelde de nodige financiële middelen ter beschikking92.

87 SAG., Modern Archief, Reeks G 12 (Moderne bouwvergunningen), MF 444, 1893-M-2.

88 Het is niet ondenkbaar dat de voorgevel voordien reeds bepleisterd was. De vormgeving van de dakkapel, die een nauw verwantschap vertoont met de klokgevels, wijst op een mogelijk achttiende-eeuwse bepleistering.

89 SAG., Reeks SCMS (Dossiers), nr. 89, Processen-verbaal (origineel) van de vergaderingen van de Commissie, 1887-1899, s.f. (1 juni 1893).

90 Victor Van der Haeghen werd aangesteld ter vervanging van Prosper Claeys. IN: SAG, Reeks SCMS (Dossiers), nr. 89, Processen-verbaal (origineel) van de vergaderingen van de Commissie, 1887-1899, s.f. (22 juli 1893).

91 SAG, Reeks SCMS (Dossiers), nr. 89, Processen-verbaal (origineel) van de vergaderingen van de Commissie, 1887-1899, s.f. (25 oktober 1893).

92 SAG, Reeks SCMS (Dossiers), nr. 89, Processen-verbaal (origineel) van de vergaderingen van de Commissie, 1887-1899, s.f. (18 januari 1896). 


\section{DE SPIJKER AAN DE PENSMARKT}

In maart 1904 meldde Armand Heins dat de bepleistering aan de voorgevel van de Spijker loskwam ${ }^{93}$. Dit leek het geschikte moment om de eigenaar voor te stellen de gevel te ontdoen van zijn bepleistering en hem zo in zijn volle glorie te herstellen. De subcommissie die zich met deze opdracht inliet bestond uit kanunnik Van Den Gheyn, Ernest Lacquet en Armand Heins. De toenmalige eigenaar was Omer Van der Stricht, een telg van de brouwersfamilie Van der Stricht-Gevaert (Brouwerij Excelsior) die carrière had gemaakt als professor in de geneeskunde aan de Universiteit Gent. Hij werd in eerste instantie vertegenwoordigd door zijn vrouw die het voorstel van de Stedelijke Commissie maar lauw onthaalde. Zij weigerde de kosten van het onderzoek aan de voorgevel te betalen maar had er niets op tegen indien de Stedelijke Commissie het project zelf financierde ${ }^{94}$. Het uitzonderlijke belang van het pand liet de Stedelijke Commissie niet onverschillig en ook de Stad Gent werd bereid bevonden een bijdrage te leveren. De leiding over de werkzaamheden werd toevertrouwd aan architect Ernest Van Hamme, de uitvoering zou geschieden door aannemer Hoste 95 . Naarmate de werken vorderden, betoonde mevrouw Van der Stricht geleidelijk aan meer interesse ${ }^{96}$. Eenmaal de voorgevel was vrijgemaakt, bleken de ingrepen grootschaliger dan aanvankelijk gepland. Er diende meer metselwerk vervangen te worden en vele bogen boven de vensteropeningen waren aan vernieuwing toe ${ }^{97}$. Dit alles leidde tot de vraag aan de stad om de subsidie op te trekken van 500 frank naar 1000 frank, een verzoek waarmee werd ingestemd gezien de oudheidkundige waarde van de Spijker ${ }^{98}$. Bij het verwijderen van het pleisterwerk was daarenboven gebleken dat alle vensters op de begane grond in oorsprong gelijkgrondse toegangen waren. Architect Van Hamme opteerde ervoor om net als op de eerste verdieping ook op de begane grond de deurvensters te herstellen zodat het oorspronkelijk lagere straatniveau meer uitgesproken in het straatbeeld aanwezig was. De vier toegangsdeuren op de begane grond kregen langs weerszijden een ijzeren handgreep en aan de gerestaureerde voorgevel was geen plaats meer voor de bepleisterde dakkapel.

93 SAG, Reeks SCMS (Dossiers), nr. 90, Processen-verbaal (origineel) van de vergaderingen van de Commissie, 1900-1904, f. 84 (11 maart 1904).

94 SAG., Reeks SCMS (Dossiers), nr. 90, Processen-verbaal (origineel) van de vergaderingen van de Commissie, 1900-1904, f. 89 (26 maart 1904).

95 SAG., Modern Archief, Reeks VII (Kleine Werken), nr. 4.020 (1994), Gevels conventie, o.a. Pensmarkt 3, 5, 7, 9, brief 11 april 1904.

96 SAG., Reeks SCMS (Dossiers), nr. 90, Processen-verbaal (origineel) van de vergaderingen van de Commissie, 1900-1904, f. 91 (7 juli 1904).

97 SAG., Modern Archief, Reeks VII (Kleine Werken), nr. 4.020 (1994), Gevels conventie, o.a. Pensmarkt 3, 5, 7, 9, brief 5 augustus 1904.

98 SAG., Reeks SCMS (Nota's straten), doos 22, Hooiaard, brief 25 oktober 1904. 


\section{JELLE MOENS}

Voor de werken van start gingen, heerste er nog twijfel over de kunsthistorische waarde van de Spijker ${ }^{99}$, maar met de voltooiing van de restauratie werd alom de loftrompet geblazen. De restauratie werd beschouwd als een goed geslaagde onderneming die zich tot voorbeeld mocht stellen voor vele andere eigenaars van oude panden ${ }^{100}$ (afb. 25). In het jaarverslag van de Stedelijke Commissie kwam de restauratie van de voorgevel van de Spijker als volgt aan bod $^{101}$ : De Commissie heeft zich bijzonderlijk bezig gehouden met de herstelling van verschillige voorgevels van bijzondere huizen. De onderhandelingen aangeknoopt voor de herstellingen van den Spijker, het belangrijkste stapelhuis (XIle-XIle eeuw) gelegen aan de oever van de Lei, Hooiaard, en welke thans vier woonhuizen bevat, werden met welslagen bekroond. De Commissie was gelukkig in den heer Van der Stricht een eigenaar te vinden welke al het belang begreep van eene herstelling gedaan volgens de regelen der oudheidkunde. Het is een echt gedenk-gebouw dat het daglicht herziet, na zoolang misvormd geweest te zijn door menigvuldige lagen pleister. De Stad is tusschengekomen voor duizend frank in dit uitmuntend werk, dat in september 1904 voltooid werd, onder het bestuur van den heer bouwkundigen E. Van Hamme, bijgestaan door den afgevaardigde der Commissie, den heer Ernest Lacquet.

Gelijktijdig met de restauratie van de voorgevel besloot Van der Stricht een perceelswijziging door te voeren ${ }^{102}$. De percelen 15 bis en 17 , die zich op de begane grond beperkten tot het voorhuis, werden doorgetrokken in de achterbouw en in het achterliggende perceel (afb. 26).

\section{De restauratie van de achtergevel en het optrekken van nieuwe bijgebouwen (1911)}

Kort na de restauratie van de voorgevel vestigde de Stedelijke Commissie haar aandacht op de achtergevel van de Spijker ${ }^{103}$. De beeldbepalende impact op het Groot Vleeshuis en op de zichtlijn tussen de Grasbrug en de Vleeshuisbrug, geeft aan deze achtergevel een niet te onderschatten waarde. De restauratie werd binnen de Stedelijke Commissie voorbereid door een sub-

99 Artikel uit Gazette van Gent (3 augustus 1904), IN: SAG., Nota's Vanderhaeghen, S 1 (Spijker).

100 Artikel uit Flandre Liberale (9 oktober 1904), IN: UGent, Fonds Vliegende Bladen, III S 29, Spijker Hooiaard, Artikel uit Volksbelang (s.d.), IN: UGent, Fonds Vliegende Bladen, II S 57 Spijker.

101 V. VAN DER HAEGHEN, Rapport sur les Traveaux de la Commission des Monuments de Gand en 1904, Gand, 1905, p. 2.

102 AKG., Mutatieschetsen 207, Gent, $3^{\mathrm{e}}$ Afdeling, sectie C, $1^{\mathrm{e}}$ blad, nrs. 15, 15 bis, 17, 18, 1905.

103 SAG., Reeks SCMS (Dossiers), nr. 93, Processen-verbaal (origineel) van de vergaderingen van de Commissie, 1909-1910, f. 102 (29 juli 1910). 


\section{DE SPIJKER AAN DE PENSMARKT}

commissie waarin ook architect Ernest Van Hamme zetelde die de plannen zou uittekenen ${ }^{104}$. Aanvankelijk leek er binnen de Stedelijke Commissie enige twijfel te bestaan over de vormgeving van de trapgevels die Van Hamme voorstelde maar de plannen werden toch goedgekeurd en de architect beloofde eventuele ontdekkingen, die al dan niet tijdens de werken aan het licht zouden komen, te melden ${ }^{105}$. In augustus 1911 startte aannemer Garré de werken, die ten einde liepen in november van datzelfde jaar ${ }^{106}$. Het baksteenmetselwerk werd vervangen waar nodig en de spitse glasruitjes in de raamkozijnen werden ingeruild voor eenvoudige, moderne ruiten. Op de verdiepingen kregen alle doorbrekingen een schouderboogvormige afdekking die gevat zit tussen een onder- en bovendorpel. Om het geheel te vervolledigen, werden ook negblokken en ontlastingsbogen aangebracht.

De bouwvallige staat van de bijgebouwen achter de Spijker vormde echter een belemmering bij de uitvoering van de plannen. De Stedelijke Commissie wees Van der Stricht op de inspanningen die de Stad Gent zich had getroost om de Graslei en de nabije omgeving op te waarderen. Zijn bijgebouwen stonden in schril contrast tot dit pittoreske stadsgezicht ${ }^{107}$. Volgens architect De Waele moesten de 'koterijen' afgebroken worden zodat de toekomstig gerestaureerde gevel in zijn volle glorie kon aanschouwd worden ${ }^{108}$. Van der Stricht werd overtuigd, waarop architect Van Hamme een reconstructie van de bijgebouwen ontwierp dat harmonieerde met het restauratieplan van de achtergevel (afb. 27).

\section{De erkenning als conventiegevel (1912)}

Rond de eeuwwisseling onderging de visie op monumentenzorg een nieuwe wending; het principe om grote monumenten vrij te maken werd meer en meer in vraag gesteld terwijl de belangstelling voor de historisch gegroeide context toenam ${ }^{109}$. De omgeving zoals deze zich doorheen de eeuwen rondom een monument had weten te ontwikkelen, werd als waardevol ingeschat en maakte het mogelijk de monumentale schaal in de juiste verhouding te

104 SAG., Reeks SCMS (Dossiers), nr. 93, Processen-verbaal (origineel) van de vergaderingen van de Commissie, 1909-1910, f. 102 (29 juli 1910).

105 SAG., Reeks SCMS (Dossiers), nr. 94, Processen-verbaal (origineel) van de vergaderingen van de Commissie, 1910-1911, f. 2 (30 september 1910).

106 SAG., Reeks SCMS (Nota's Straten), doos 22, Hooiaard.

107 SAG., Modern Archief, Reeks VII (Openbare Werken), nr. 4.020 (1994), Gevels conventie, o.a. Pensmarkt 3, 5, 7, 9, brief 23 november 1908.

108 SAG., Modern Archief, Reeks VII (Openbare Werken), nr. 4.020 (1994), Gevels conventie, o.a. Pensmarkt 3, 5, 7, 9, brief 30 november 1908.

109 H. STEYNEN, De onvoltooid verleden tijd. Een geschiedenis van de monumenten- en landschapszorg in België, 1835-1940, Brussel, 1998, p. 225. 


\section{JELLE MOENS}

bekijken. Indirect bracht dit nieuwe gedachtengoed ook een groeiende belangstelling teweeg voor privé-woningen, zogenaamde 'kleinere' monumenten en voor verbanden tussen gebouwen.

In Gent vormde de restauratie van het Gravensteen een eerste gelegenheid om deze visie aan de praktijk te toetsen. Na de ontbloting van de burcht wenste men de omliggende straten en het Sint-Veerleplein om te vormen tot een decor waarin het waardevolle, prestigieuze karakter van het Gravensteen beter tot zijn recht kwam. Voor de te restaureren gevels werd een speciale akte van servituut ten voordele van het Gravensteen afgesloten tussen de eigenaars in kwestie en de Stad Gent, waarbij de kosten werden gedragen door de stad en de staat als onderdeel van de Gravensteen-overeenkomst ${ }^{110}$.

Na de succesvolle 'herstellingen' rondom het Graventeen, wou men ook andere vooraanstaande historische panden in de kijker plaatsen en hun bijzondere relatie met de Gentse stadsgeschiedenis beklemtonen. Om het bouwkundige karakter van de nabije omgeving te vrijwaren, en waar nodig te versterken, werd het principe van de conventiegevels ingevoerd. Een conventie is letterlijk een overeenkomst tussen twee of meer partijen omtrent wederzijds in acht te nemen regels. In een notariële akte werd vastgelegd dat de Stad Gent zich ertoe verbond de conventiegevels te restaureren en te onderhouden tot een diepte van 75 centimeter gerekend vanaf het parement. De kosten vielen ten laste van de stedelijke begroting en het contract werd opgesteld zonder opgave van einde van overeenkomst. Dit alles geschiedde met de uitdrukkelijke vermelding dat het contract van erfdienstbaarheid 'non-modificandi' was gevestigd. De eigenaars mochten met andere woorden onder geen beding wijzigingen aan de gevel aanbrengen als ze hiervoor geen toestemming van de Stad hadden verkregen. Zo bouwde de Stad Gent de garantie in als zouden de historische gevels ongeschonden bewaard blijven. In ruil betaalden de eigenaars aan de Stad een jaarlijkse cijnsbelasting die werd berekend volgens het aantal strekkende meter van de gevelbreedte.

Toen architect De Waele in juli 1910 voorstelde om de achtergevel van de Spijker te restaureren, stelde het College van Burgemeester en Schepenen zich de vraag of deze restauratie niet kon doorgaan in het kader van een erkenning als conventiegevel ${ }^{111}$. De achtergevel bevond zich immers in het zicht van het Gravensteen, gezien van op de Grasbrug, en lag vlak naast het Groot Vleeshuis. Architect Van Hamme en Henry de Smet de Naeyer onderhandelden als vertegenwoordigers van de Stad in deze zaak en kwamen tot een over-

110 A. CAPITEYN, Gent in weelde herboren. Wereldtentoonstelling 1913 , Gent, 1988, p. 65.

111 SAG., Modern Archief, Reeks VII (Openbare Werken), nr. 4.020 (1994), Gevels conventie, o.a. Pensmarkt 3, 5, 7, 9, brief 4 november 1910. 


\section{DE SPIJKER AAN DE PENSMARKT}

eenkomst met eigenaar. In januari 1911 meldde Van der Stricht dat hij akkoord ging met alle clausules die sloegen op een eventuele restauratie als conventiegevel ${ }^{112}$. Voor de achtergevel leek de zaak beklonken maar over de voorgevel heerste enige verwarring. De Stad Gent had de restauratie gesubsidieerd wat maakte dat voor de voorgevel une simple servitude de conservation dans l'état actuel gold ${ }^{113}$. Dit hield in dat de werken door de Stedelijke Commissie waren goedgekeurd en dat de gevel in geen geval mocht gewijzigd worden ${ }^{114}$. Het College liet aan notaris Maeterlinck weten dat aan de akte van conventie voor de achtergevel nog een erkenning van de onderhoudsovereenkomst voor de voorgevel moest worden toegevoegd ${ }^{115}$. Eigenaar Van der Stricht verklaarde zich akkoord met de eisen van de stad en op 14 juni 1912 werd de akte van erfdienstbaarheid voor de Spijker ondertekend.

\section{Besluit}

De erkenning van de Spijker als beschermd monument in 1952 blijkt ruim vijftig jaar na datum geen garantie te bieden voor een vakkundig onderhoud en een respectvol gebruik. Verwaarlozing en verval, dringende instandhoudingswerken aan de daken en zogenaamde verfraaiingscampagnes legden een zware hypotheek op dit schitterende Steen. De begane grond wordt thans ten dienste gesteld van twee horecazaken, terwijl de verdiepingen reeds enkele jaren leegstaan en geleidelijk aan verkommeren. Het principe van de conventiegevels is daarenboven voorbijgestreefd maar nog niet afgevoerd wat resulteert in een grauwe, verwaarloosde buitengevel die dit unieke stapelhuis een troosteloze aanblik biedt, waar menig Gentenaar of toerist geen acht op slaat.

112 SAG., Modern Archief, Reeks VII (Openbare Werken), nr. 4.020 (1994), Gevels conventie, o.a. Pensmarkt 3, 5, 7, 9, brief 25 januari 1911.

113 SAG., Modern Archief, Reeks VII (Openbare Werken), nr. 4.020 (1994), Gevels conventie, o.a. Pensmarkt 3, 5, 7, 9, brief 7 februari 1912.

114 A. CAPITEYN, Gent in weelde herboren. Wereldtentoonstelling 1913, p. 57.

115 SAG., Modern Archief, Reeks VII (Openbare Werken), nr. 4.020 (1994), Gevels conventie, o.a. Pensmarkt 3, 5, 7, 9, brief 8 maart 1912. 


\section{JELLE MOENS}

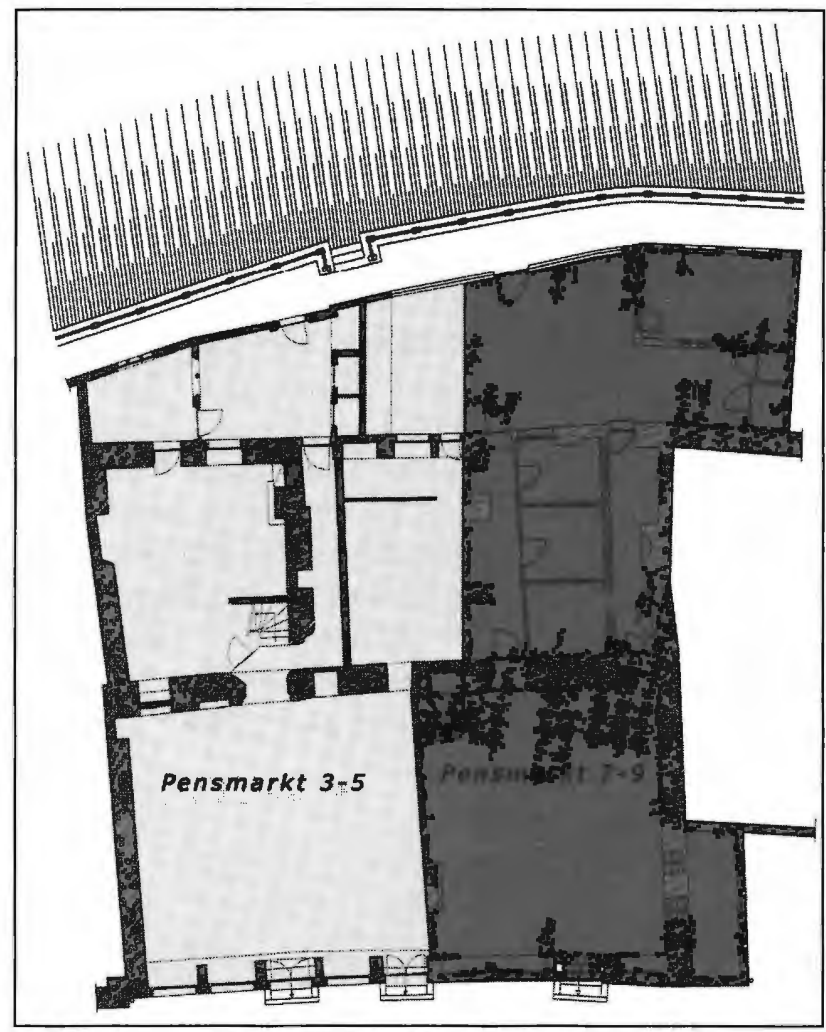

Afbeelding 1 De Spijker omvat de huisnummers 3 tot 9 aan de Pensmarkt en is thans eigendom van de Brouwerij Haacht; op de begane grond zijn twee horecazaken ondergebracht (naar plannen Studiebureau Arrow, Dossier de Spijker Pensmarkt, Plannen reconversie, opmeting begane grond, 2000) 


\section{DE SPIJKER AAN DE PENSMARKT}

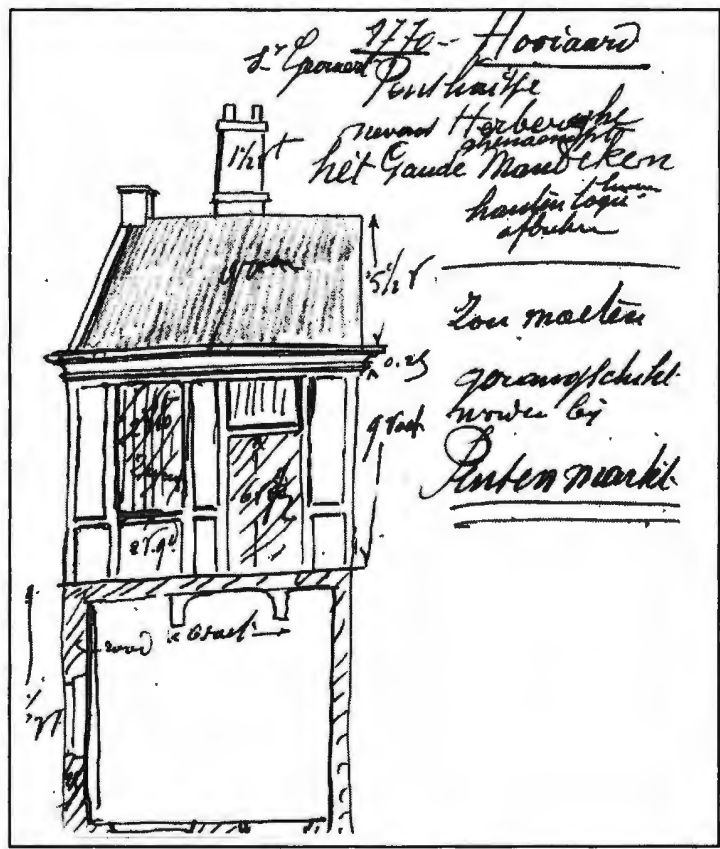

Afbeelding 2 Ontwerp voor het bijgebouwtje naast de Spijker, ingediend door Pieter de Maeght in oktober 1770. Op de bouwaanvraag staat de vermelding 'zwart' voor een vensteropening, terwijl 'groen' wijst op een leien dakbedekking (SAG., Oud Archief, Reeks 535, Huizen- Bouwaanvragen en veranderingswerken, nr. 103 (7), Hooiaard)

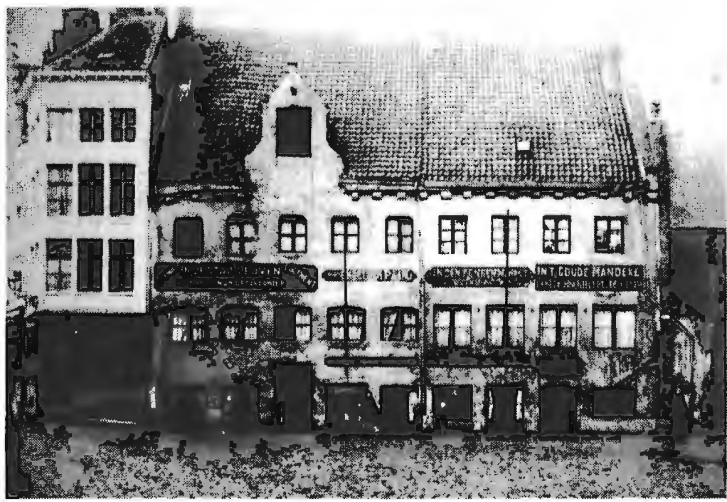

Afbeelding 3 Deze foto, die aan de hand van de namen van de uitbaters op de uithangborden kon gedateerd worden in 1898, biedt het oudste waarheidsgetrouwe beeld van de Spijker. De voorgevel draagt een eenheidsbepleistering en is getooid met een dakkapel die naar vormgeving een nauw verwantschap vertoont met de klokgevels. De verschillende vorm van de vensteropeningen valt samen met de opdeling van de Spijker in twee woningen omstreeks 1709 (SAG., Reeks SCMS, Foto's, doos 165, Hooiaard, nr. 2395) 


\section{JELLE MOENS}

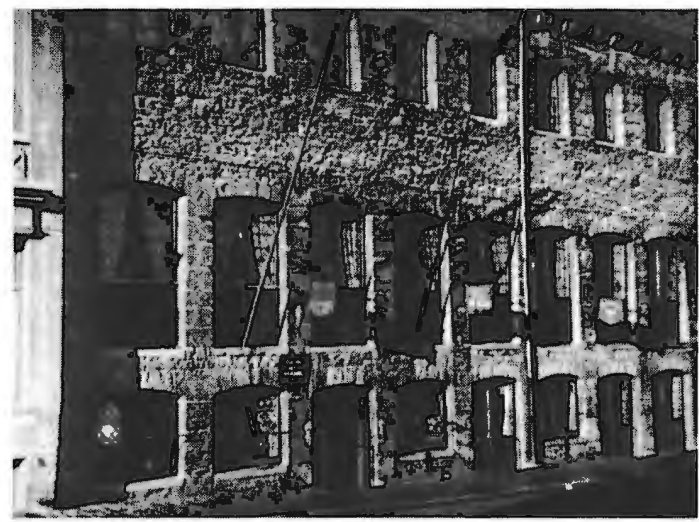

Afbeelding $4 \mathrm{Op}$ de begane grond hebben de doorbrekingen een segmentboogvormige afdekking die wordt herhaald op de eerste verdieping. Tijdens de restauratiewerken in 1904 stelde architect Ernest Van Hamme vast dat de doorbrekingen op de eerste verdieping, die tot dan toe als vensters waren ingevuld, in oorsprong deuropeningen waren (SAG., Reeks SCMS, Foto's, doos 165, Hooiaard, nr. 2390)

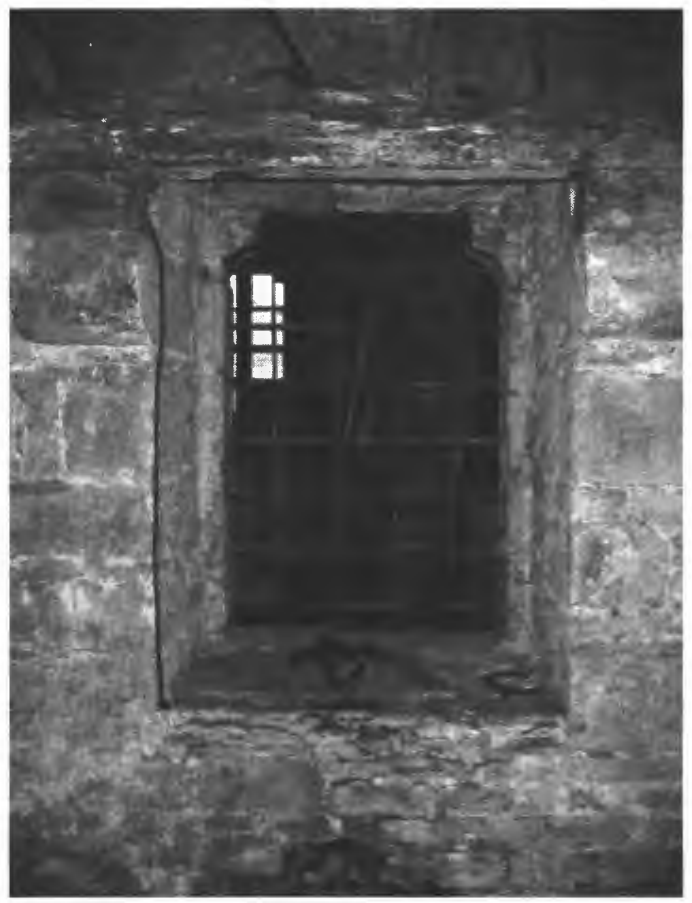

Afbeelding 5 In de voormalige achtergevel bleef een schouderboogvormige vensteropening in haar oorspronkelijke toestand bewaard. De opening wordt afgeschermd door smeedijzeren dievenstaven. Het traliewerk telt acht horizontale staven die door vier verticale staven schieten (Eigen foto, november 2005) 


\section{DE SPIJKER AAN DE PENSMARKT}

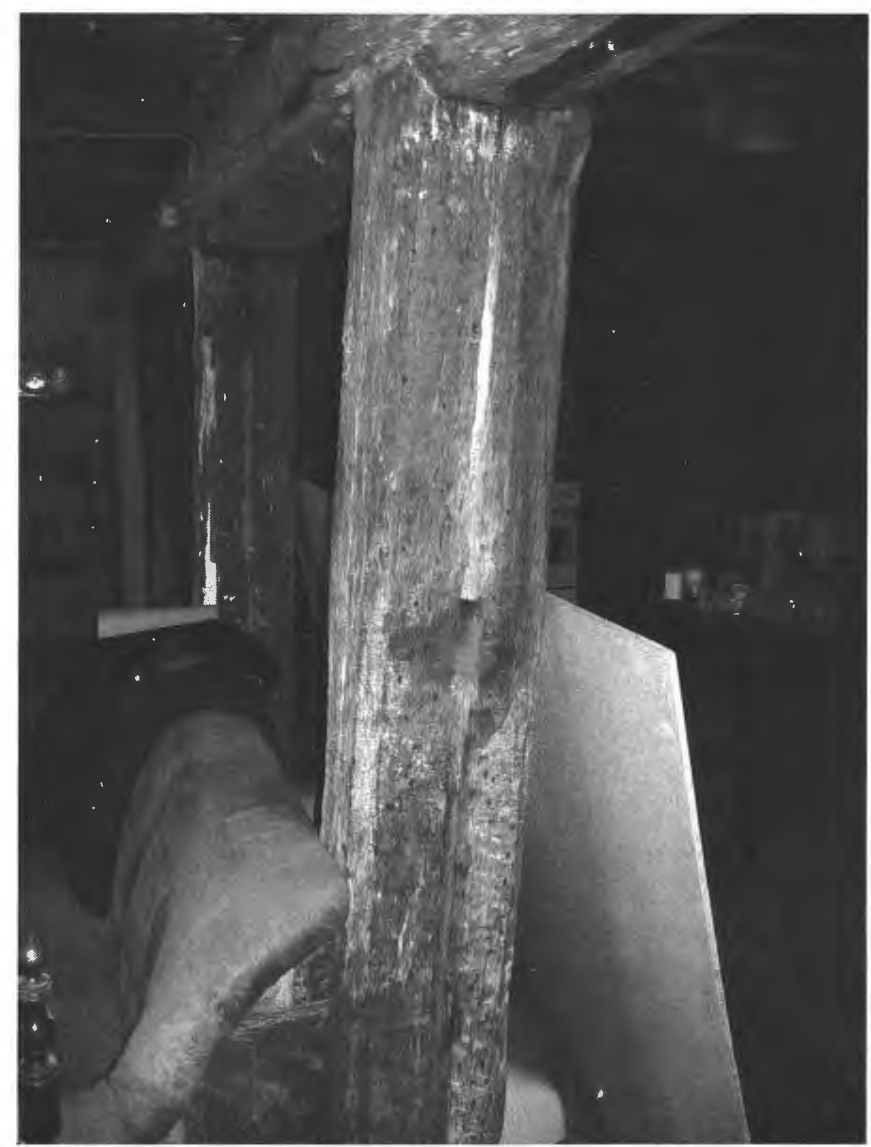

Afbeelding 6 Aan een variabel aantal zijden van de standvinken zitten gleuven die ruim twee centimeter breed zijn. In sommige gevallen, zoals te zien op de afbeelding, hebben de gleuven een verbreding tot een rechthoekige opening. Vermoedelijk werden in de gleuven schotten geschoven die, waar nodig, konden vastgezet worden met dwarsbalken, waarvoor in de standvinken openingen werden voorzien (Eigen foto, mei 2006) 


\section{JELLE MOENS}

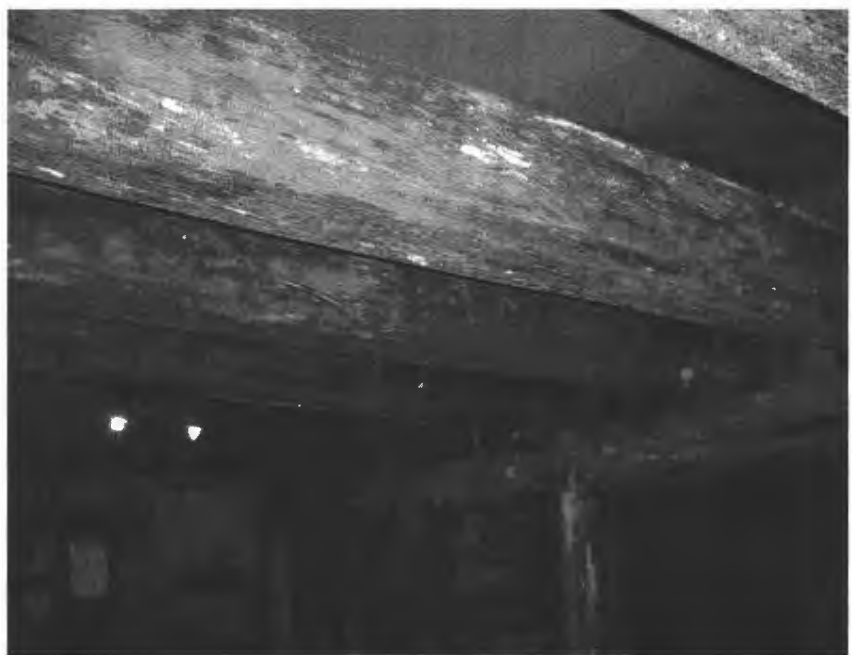

Afbeelding 7 Haaks op de onderslagbalken rusten de dwarsbalken die vrij dicht bij elkaar werden geplaatst. De dwarsbalken dragen nog sporen van een witte bekalking en vertonen de kenmerkende afgeschuinde vorm aan de hoeken, zoals te zien is op de eerste verdieping in het voorhuis van de Spijker (Eigen foto, november 2005)

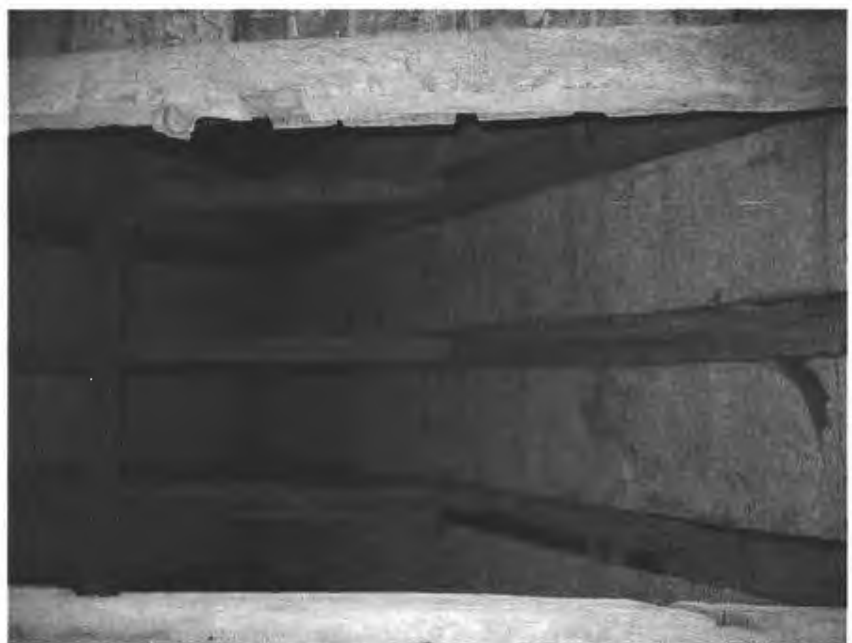

Afbeelding 8 De spantbenen van de sporenkap in het voorhuis van de Spijker zijn onderling niet met elkaar verbonden, tenzij door de hanenbalken, want er is geen nokverbinding (Eigen foto, mei 2006) 


\section{DE SPIJKER AAN DE PENSMARKT}

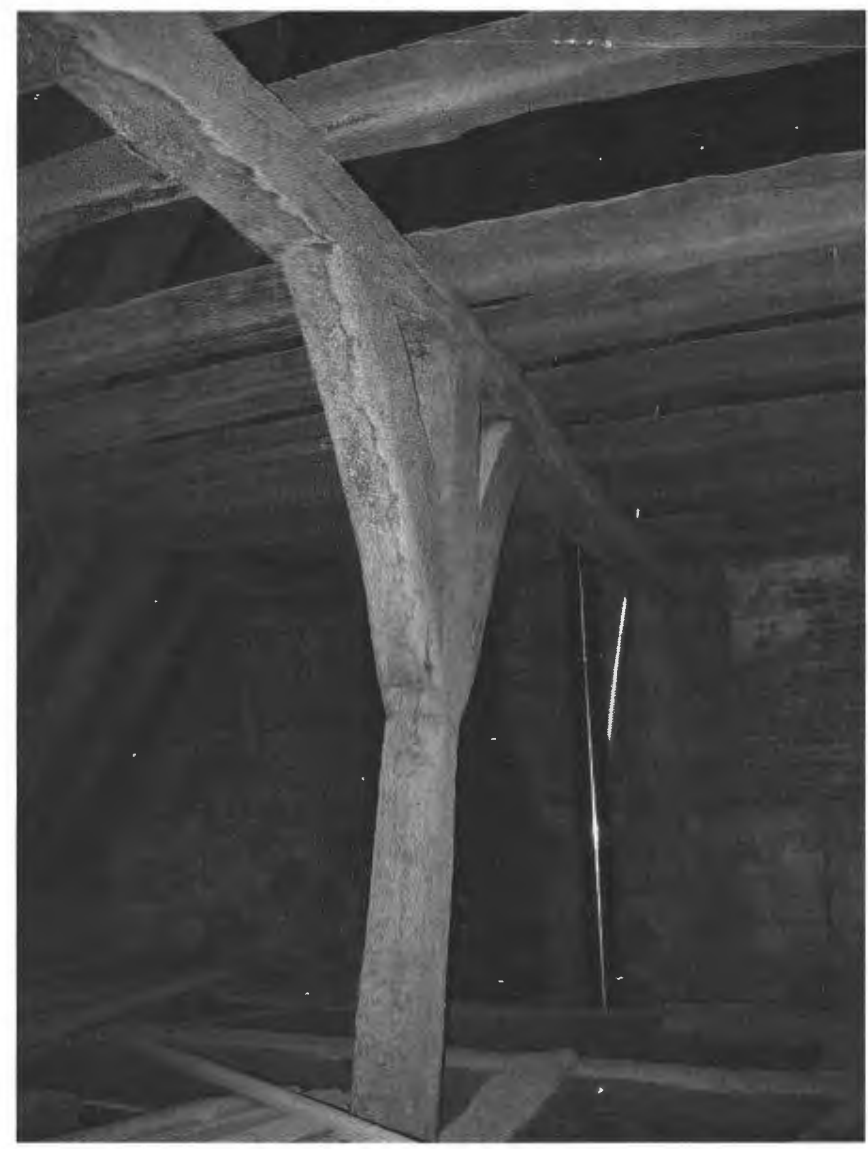

Afbeelding 9 Op de zoldervloer werden centrale standvinken met zijdelingse schoren geplaatst ter ondersteuning van de onderslagbalk. De zoldervloer werd recent verwijderd maar op de onderliggende balkenroostering zijn nog steeds drie oorspronkelijke standvinken bewaard gebleven (Eigen foto, mei 2006) 


\section{JELLE MOENS}
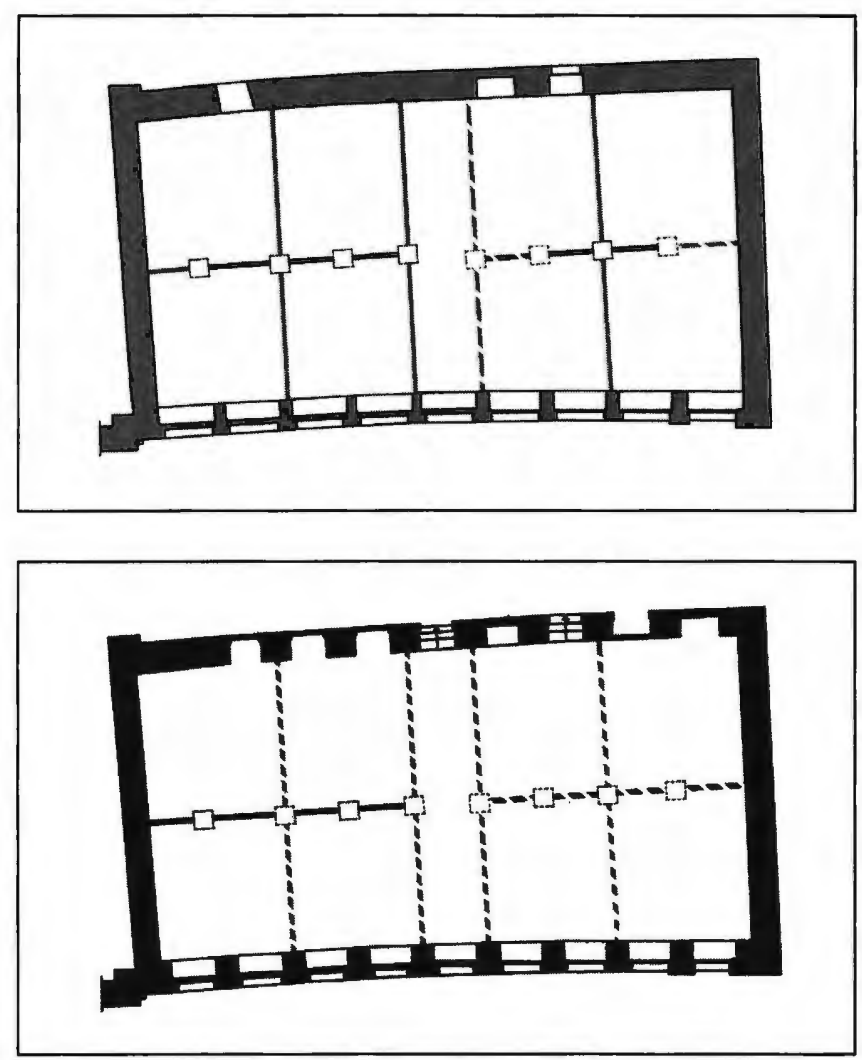

Afbeelding 10 en 11 Hypothetische reconstructie van de interne structuur op de eerste (boven) en tweede (onder) verdieping in het voorhuis van de Spijker. De donkere lijnen in de breedte van het pand duiden op de schotten die werden vastgezet met een dwarsbalk, de lichte lijnen in de diepte van het pand duiden de verplaatsbare schotten aan (naar plannen Studiebureau Arrow, Dossier de Spijker Pensmarkt, Plannen reconversie, opmeting verdieping 1 en verdieping 2,2000 ) 


\section{DE SPIJKER AAN DE PENSMARKT}

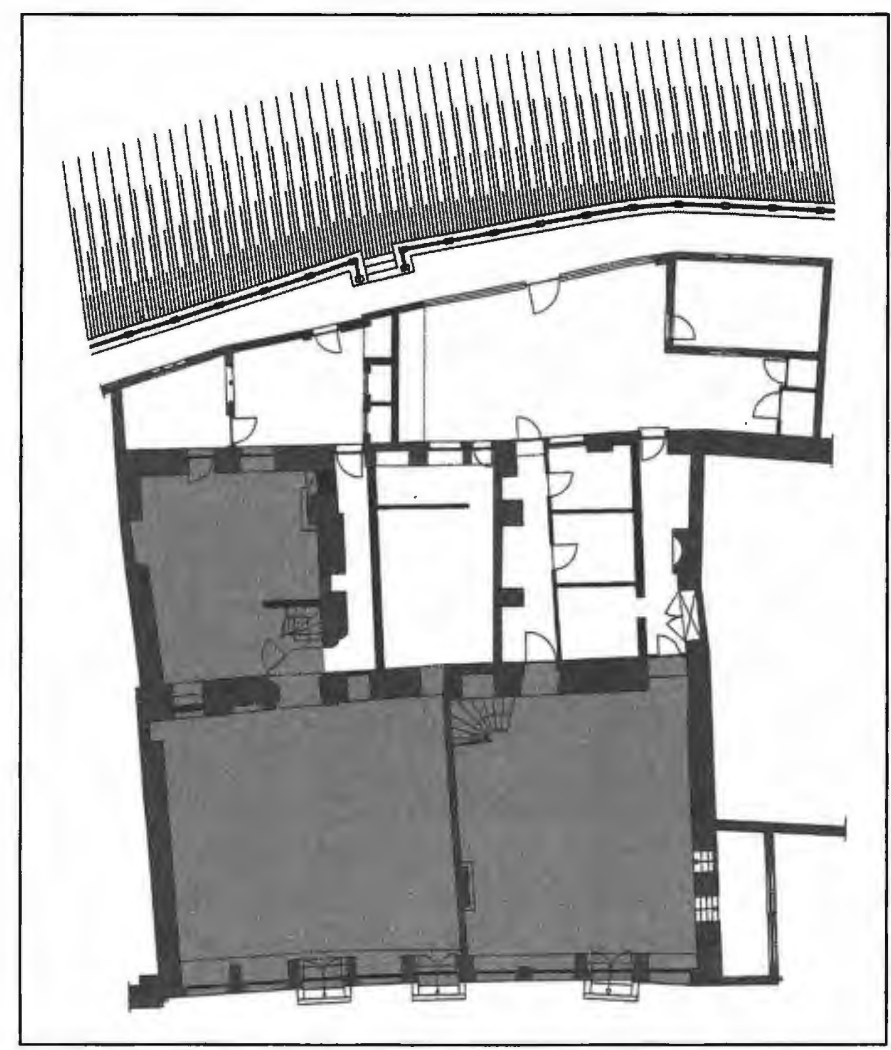

Afbeelding 12 Situering van de vierkantstructuur ten opzichte van de rechthoekige salastructuur van het voorhuis (naar plannen Studiebureau Arrow, Dossier de Spijker Pensmarkt, Plannen reconversie, opmeting begane grond, 2000) 


\section{JELLE MOENS}

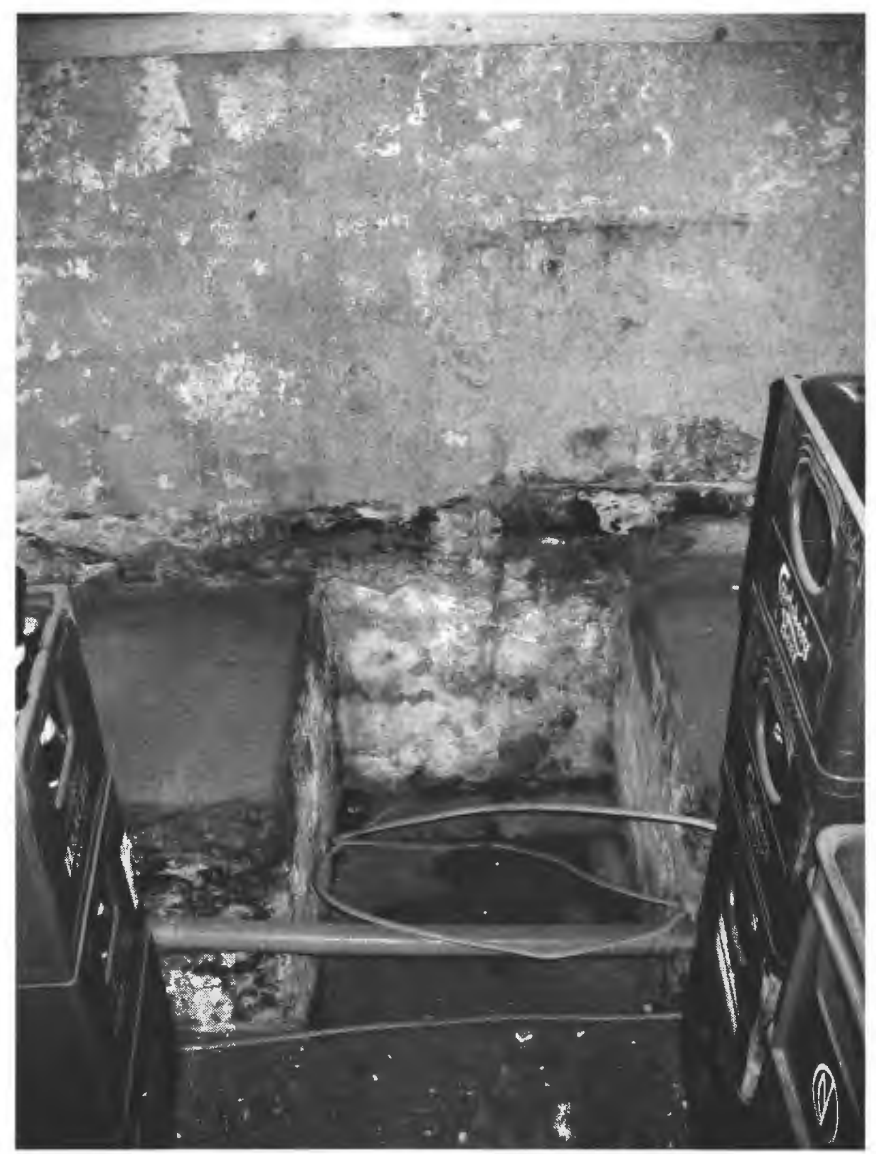

Afbeelding 13 In de dikte van de zuidelijke zijmuur staan twee verdiepte vensterbanken die volledig uit breuksteen werden vervaardigd. Ze zijn respectievelijk 47 centimeter (vooraanzicht, links) en 54 centimeter (vooraanzicht, rechts) breed. De muurplint in breuksteen is 48 centimeter hoog en draagt een onderdorpel in breuksteen van gemiddeld 10 centimeter hoog (Eigen foto, maart 2006) 


\section{DE SPIJKER AAN DE PENSMARKT}

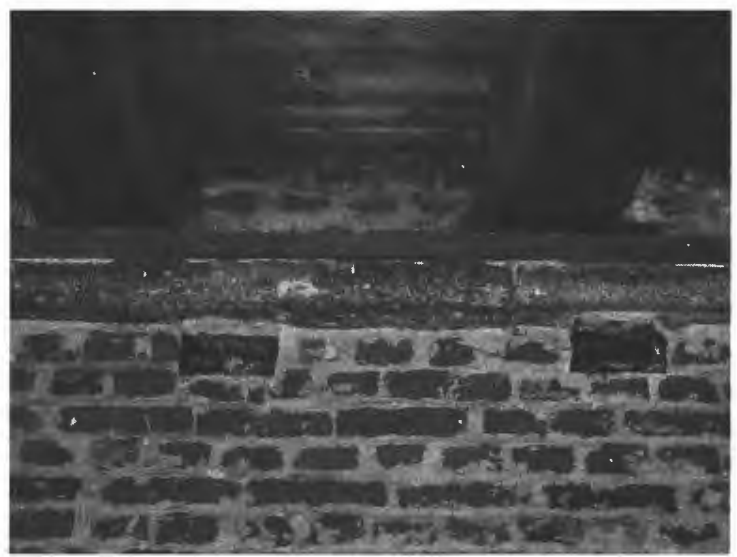

Afbeelding 14 De dwarsbalken die de kamers in de achterbouw overbruggen worden in de zijmuren ondersteund door een houten strijkbalk waaronder een uitkragende stenen lijst zit. Deze laatste wordt op zijn beurt ondervangen door kraagstenen die op een korte afstand van elkaar geplaatst werden opdat de overspanning voor de stenen lijst minimaal zou zijn (Eigen foto, maart 2006)

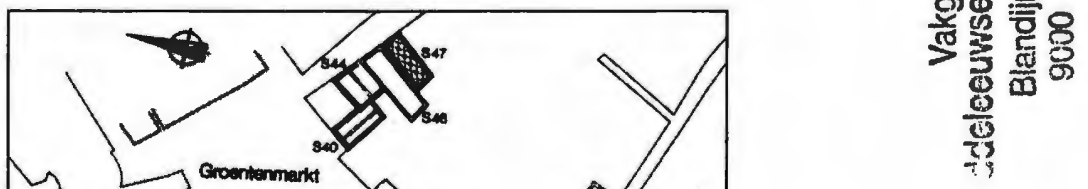

Afbeelding 15 Situering en grondplan van de constructie S 131 ten opzicht van het voorhuis van de Spijker (S 130) (uit: M. C. LALEMAN, P. RAVESCHOT, Inleiding tot de studie van de woonhuizen te Gent, periode 1000-1300: De kelders, Bijlage V) 


\section{JELLE MOENS}

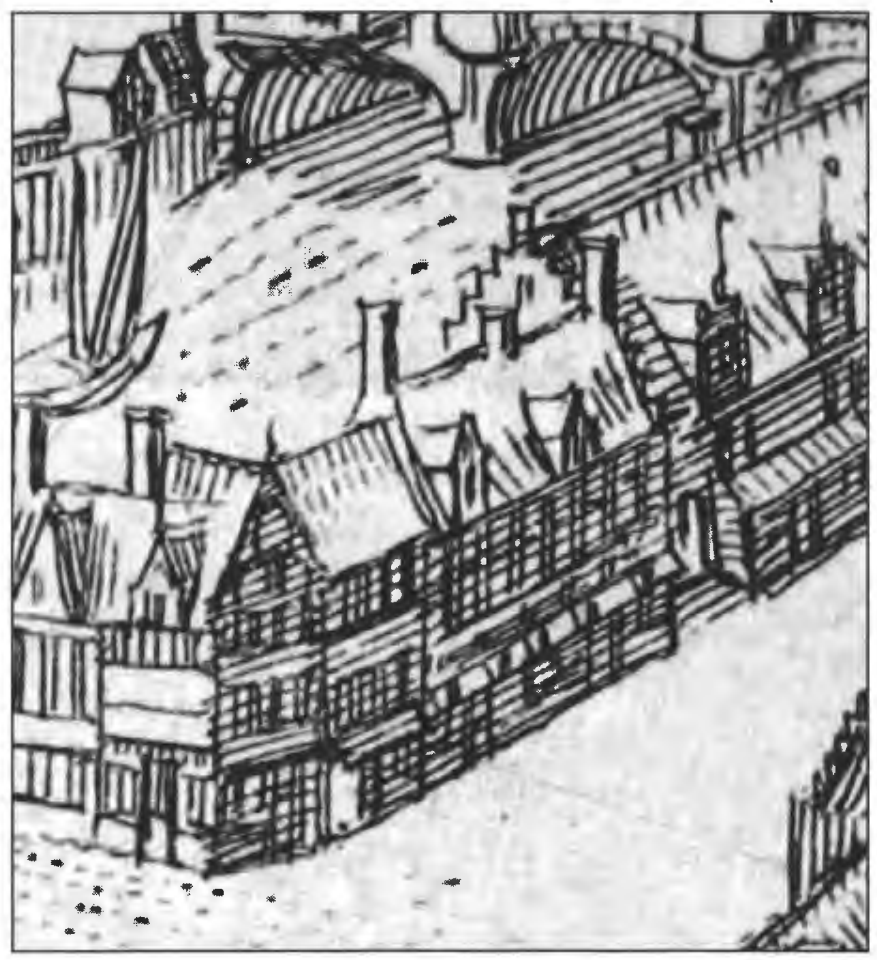

Afbeelding 16 De Spijker wordt weergegeven in vooraanzicht en draagt een zadeldak met twee schoorstenen op beide zijmuren en een schoorsteen centraal op de daknok. Enkel de noordelijke zijmuur heeft een trapgevel. Aan de straatzijde staan boven de daklijst twee dakkapellen (uit: A. SANDERUS, Flandria Illustrata. Amsterdam, 1640-1641, volume 1, p. 127, detail prent 'Ecclesia parochialis Sti. Nicolai uxta forum frumentarium Gandavi'.) 


\section{DE SPIJKER AAN DE PENSMARKT}

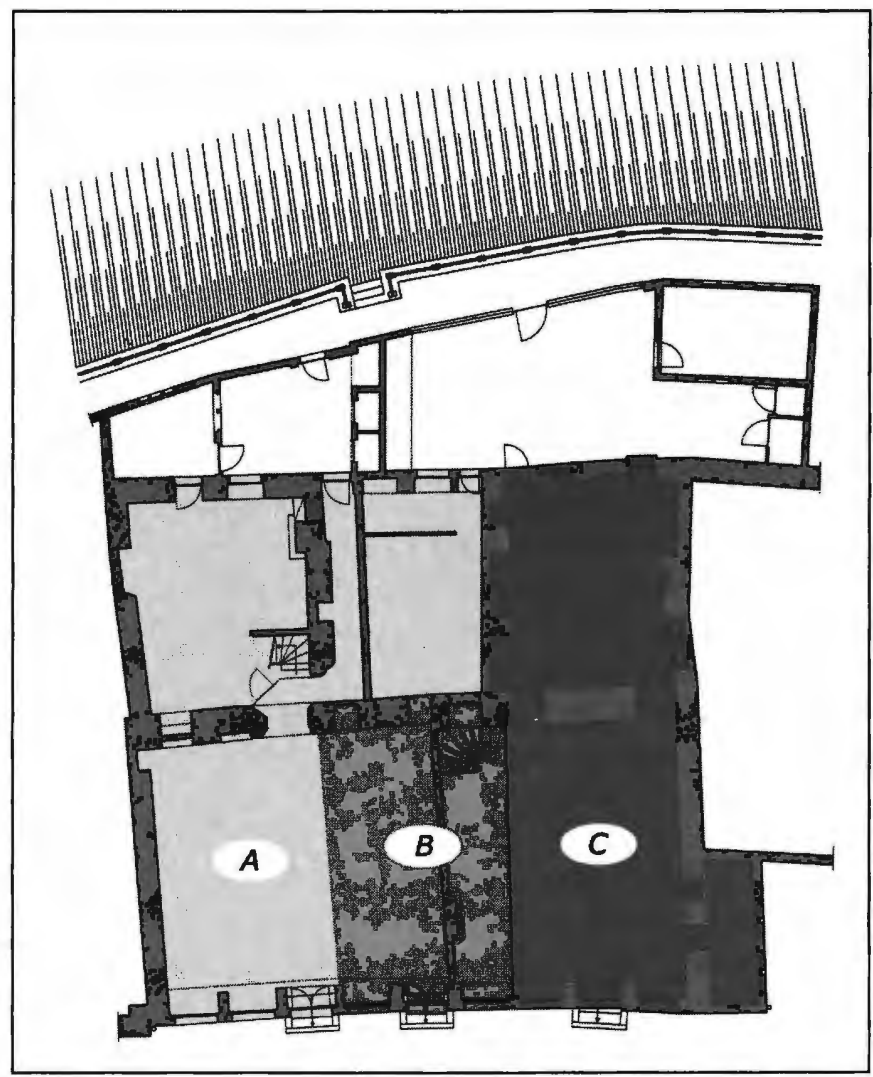

Afbeelding 17 Situering van de drie woningen in de Spijker tussen 1709 en 1712; A: woning aan de zijde van de Grasbrug (Jan Lanneaux), B: huurwoning van Guillaume Smeeckens, $\mathrm{C}$ : woning aan de zijde van het Groot Vleeshuis (Pieter de Maeght) (naar plannen van Studiebureau Arrow, Dossier de Spijker Pensmarkt, Plannen reconversie, opmeting begane grond, 2000) 


\section{JELLE MOENS}

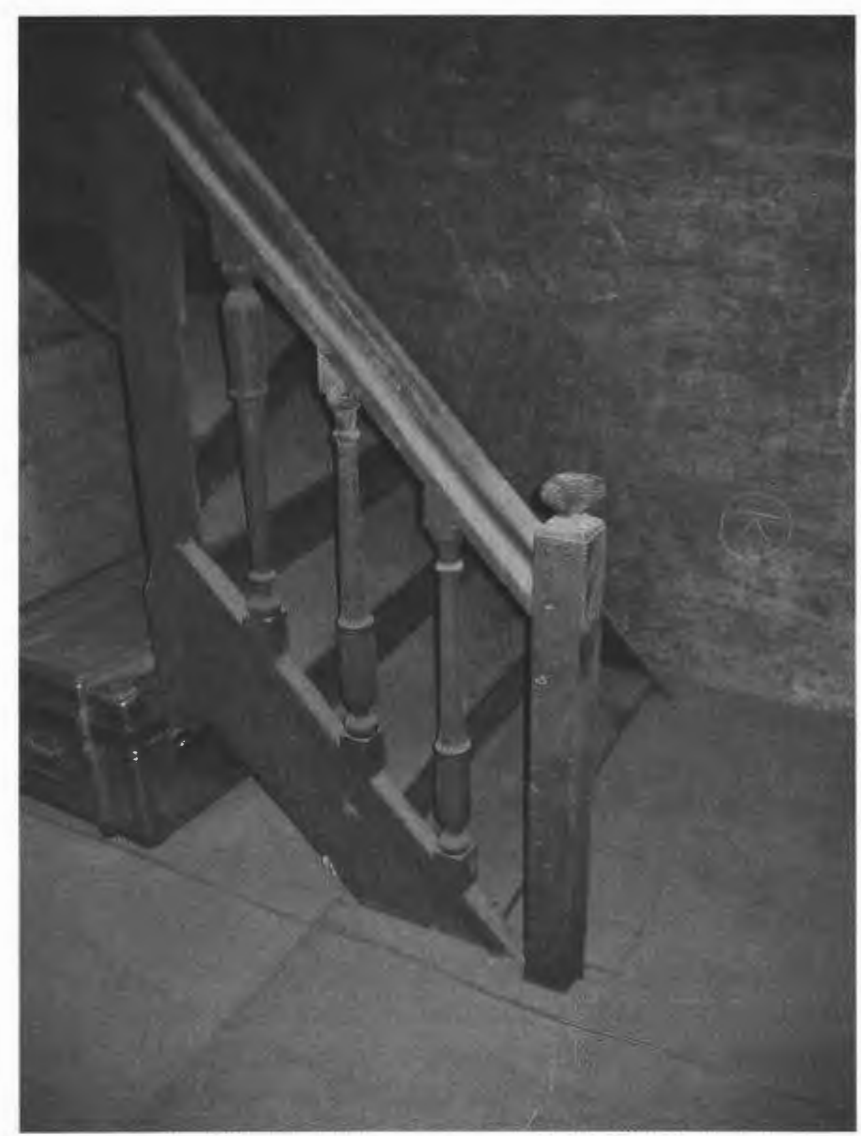

Afbeelding 18 Tegen de noordelijke scheidingsmuur op de tweede verdieping staat een trap met kwart die naar links draait. Deze achttiende-eeuwse trap heeft een trappaal met een vierkante doorsnede die wordt bekroond door een afgeknotte peervorm met vier facetten (Eigen foto, november 2005) 


\section{DE SPIJKER AAN DE PENSMARKT}

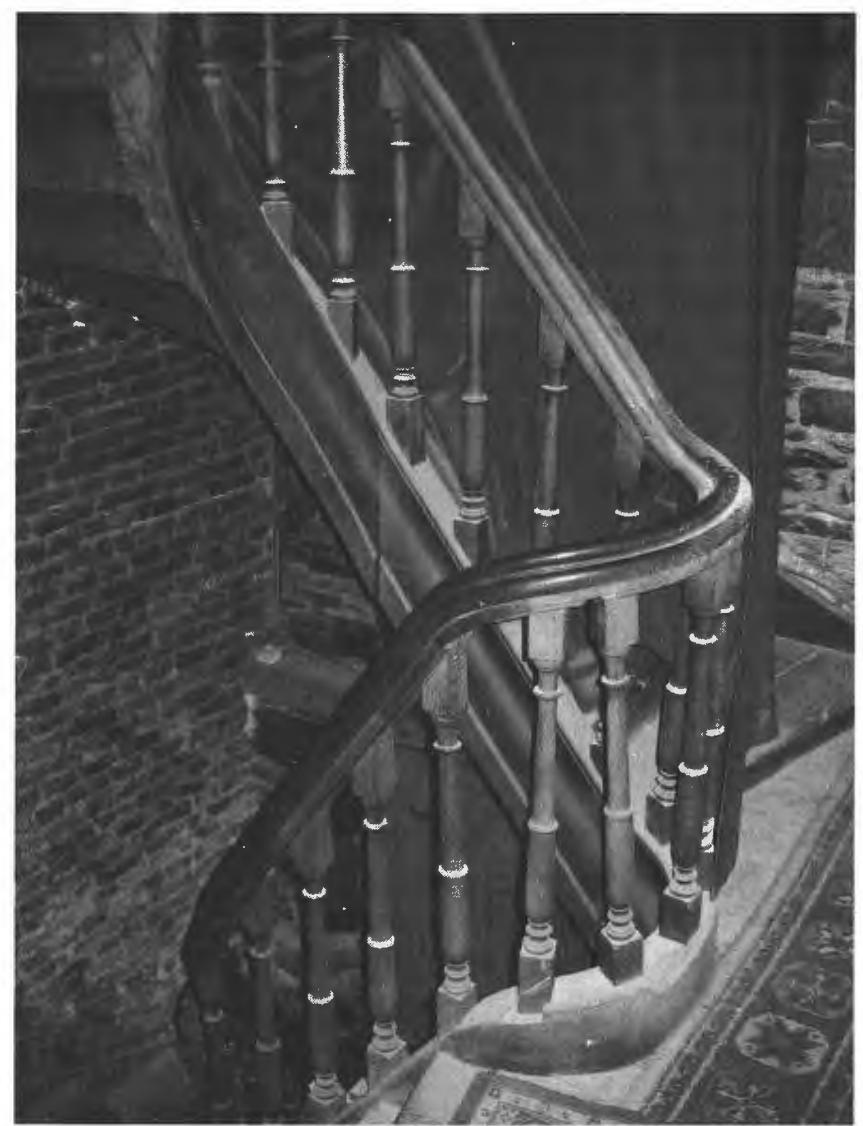

Afbeelding 19 De slingertrap verbindt de begane grond met de zolderverdieping. De vormgeving van de balusters kan naar typologie gedateerd worden tussen 1720/30 en 1775/80 (Eigen foto, februari 2006) 


\section{JELLE MOENS}

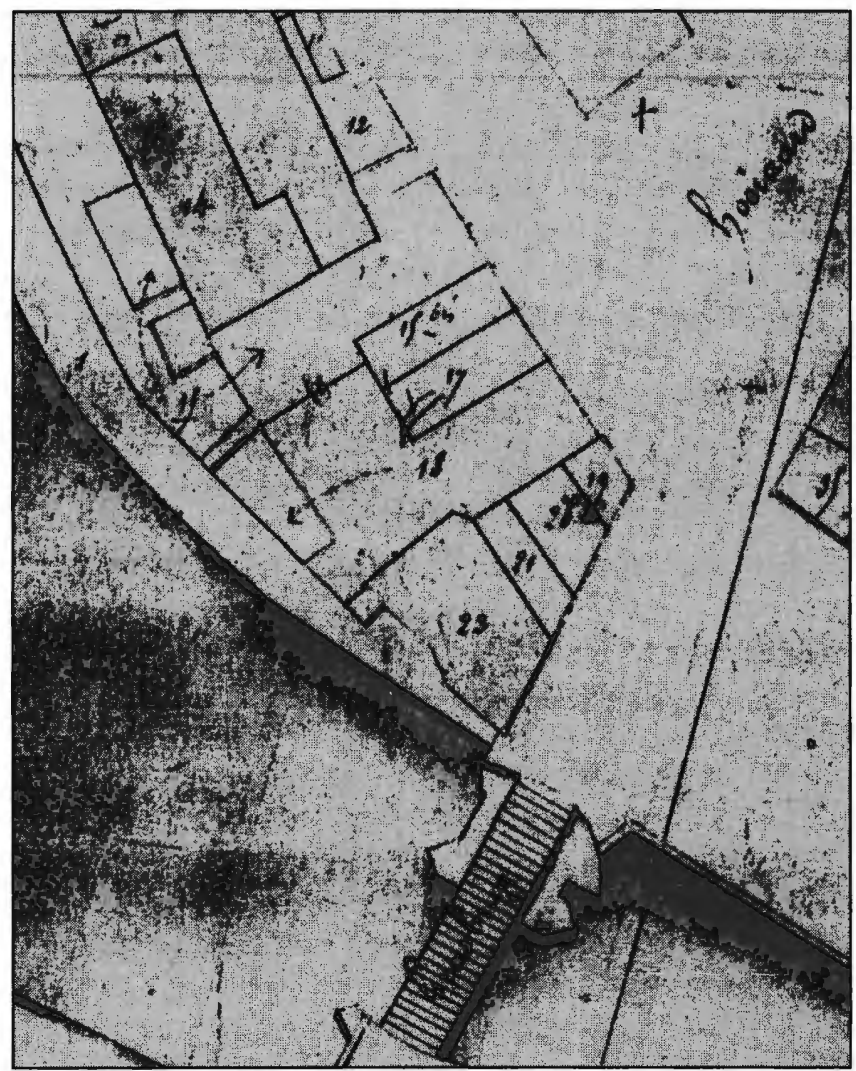

Afbeelding 20 Op het primitieve kadasterplan (circa 1835) beslaat de Spijker vier kadastrale percelen, te weten de nummers 15,15 bis, 17 en 18 . Het achtergelegen erf draagt het perceelsnummer 16 en sterkt zich uit tot achter het Groot Vleeshuis (AKG., Primitief kadasterplan, Gent, sectie C, blad 1) 


\section{DE SPIJKER AAN DE PENSMARKT}

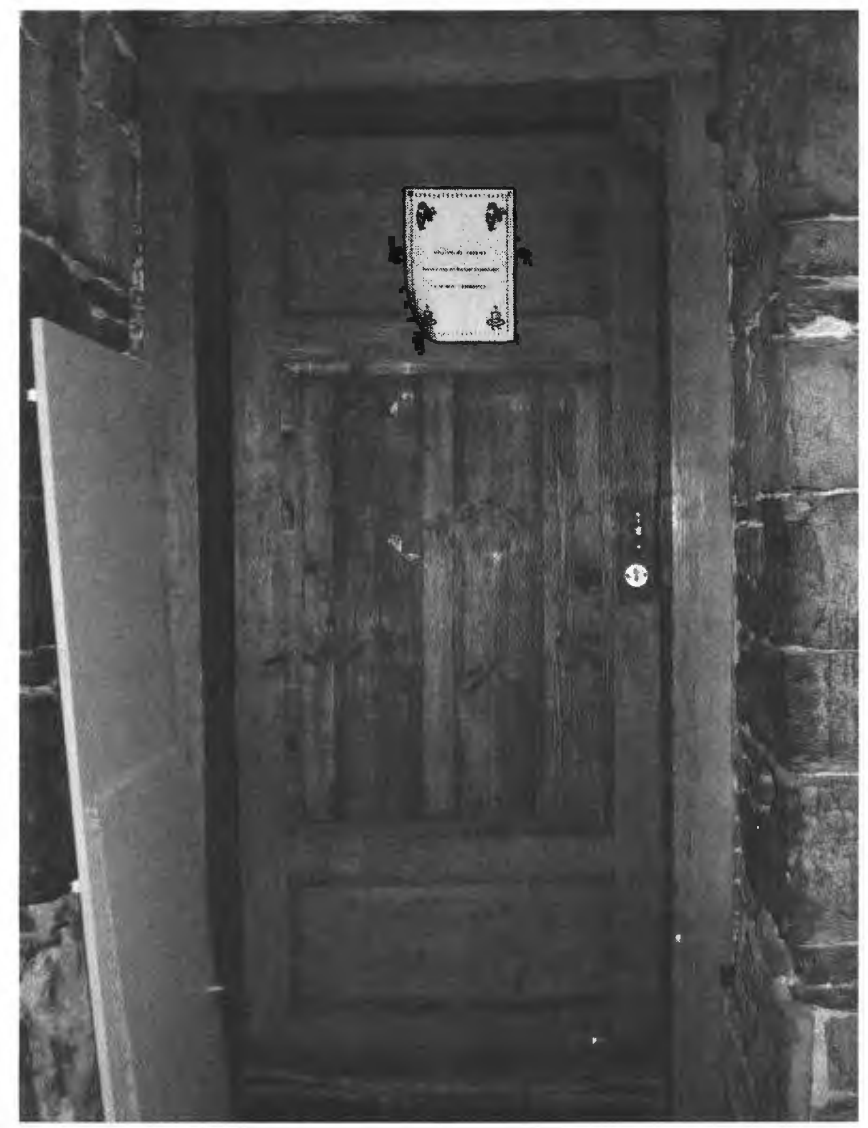

Afbeelding 21 Deze deur met driepaneelverdeling verbindt de voorkamer met de achterkamer op de eerste verdieping in de huidige Pensmarkt 7-9. Bij dit deurtype zit het grootste paneel steeds centraal ingewerkt (Eigen foto, maart 2006) 


\section{JELLE MOENS}

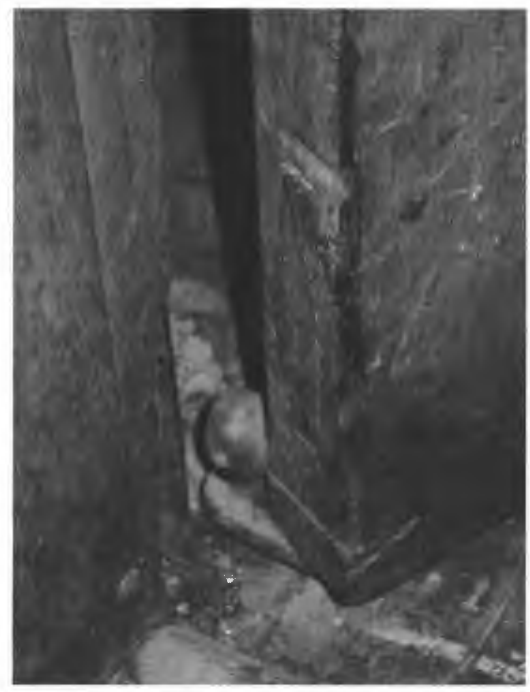

Afbeelding 22 In de empireperiode doet een nieuw scharniertype zijn intreden. Op deze afbeelding is de speun onderaan de deur te zien die met een vast plaatje zit ingewerkt in de vloerplanken. De regelschroef maakt het mogelijk om de deur, indien nodig, hoger op te schroeven (Eigen foto, maart 2006)

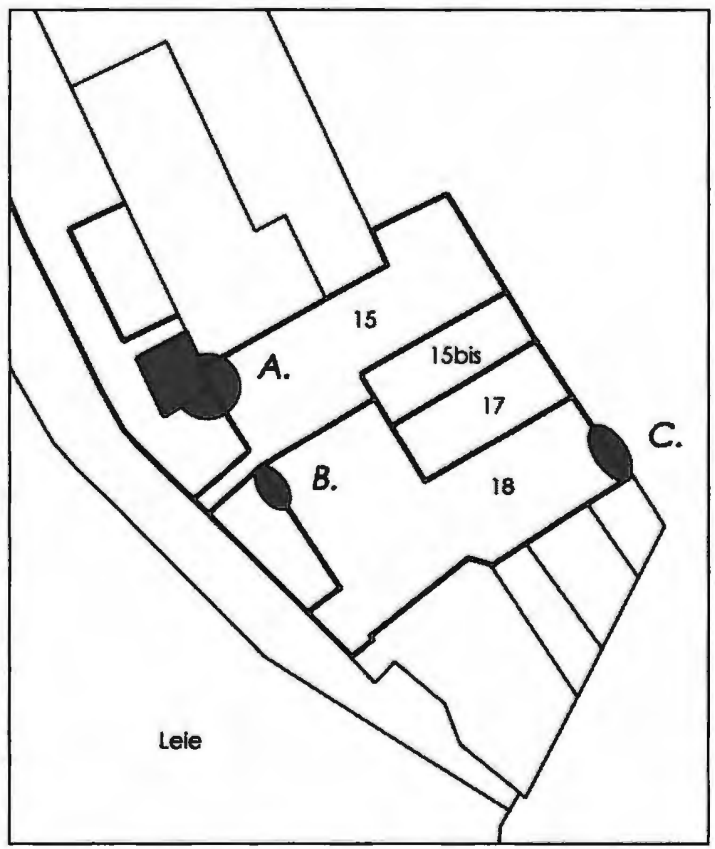

Afbeelding 23 Perceelsplan van de Spijker met situering van de ingrepen aan de achtergevel in 1850 (A) en 1852 (B) en aan de voorgevel in 1893 (C) waarvoor een bouwaanvraag werd ingediend (naar het primitief plan, AKG., Primitief kadasterplan, Gent, sectie C, blad 1) 


\section{DE SPIJKER AAN DE PENSMARKT}

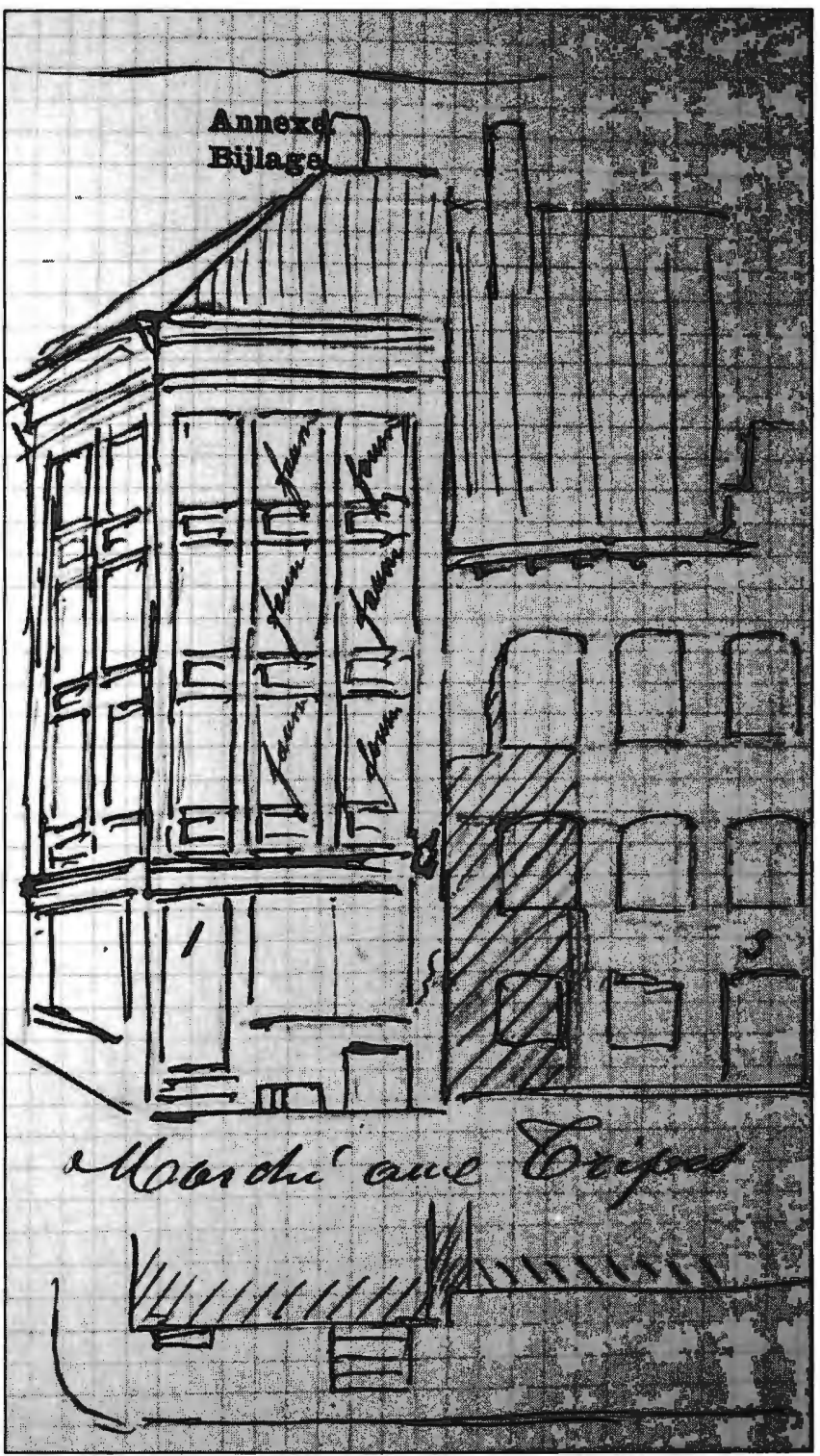

Afbeelding 24 In eerste instantie beperkte het schadebeeld zich tot de begane grond en de eerste verdieping van de eerste travee en de naastgelegen penant. Tijdens de werkzaamheden werd echter besloten ook de borstwering van de tweede verdieping te vernieuwen (SAG., Modern Archief, Reeks G 12 (Moderne bouwvergunningen), 1893-M-2) 


\section{JELLE MOENS}

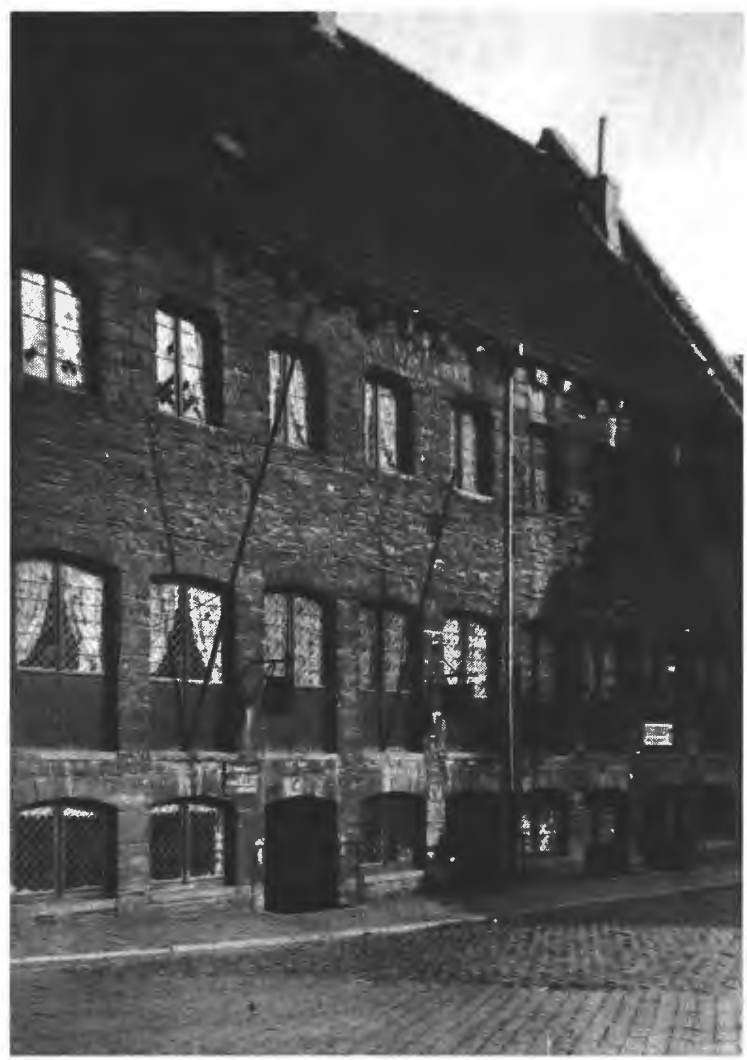

Afbeelding 25 In lokale dagbladen kon de restauratie van de voorgevel van de Spijker op veel bijval rekenen. De krant Flandre liberale (9 oktober 1904) meende dat de restauratie pas compleet zou zijn indien het voetpad aan de Hooiaard werd verlaagd: "On aurait de cette manière l'aspect complet du bâtiment tel qu'il était avant l'exhaussement du sol de la rue." (SAG., Reeks SCMS, Foto's, doos 165, Hooiaard, nr. 2389)

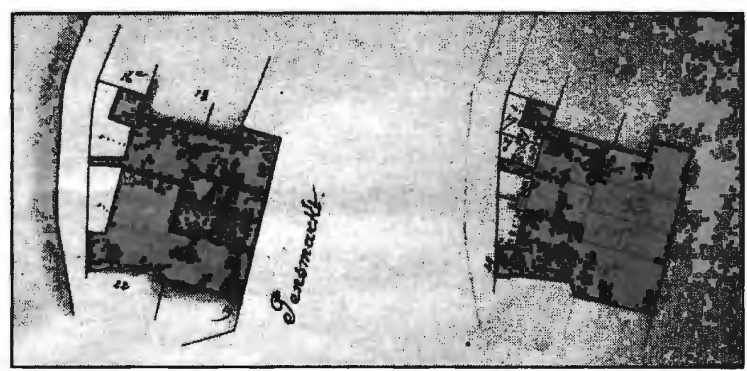

Afbeelding 26 De oude perceelsstructuur (links) werd in 1904 gewijzigd (rechts) zodat alle vier de percelen voortaan doorlopen van aan de straatzijde tot in het achtergelegen erf (AKG., Mutatieschetsen 207, Gent, $3^{\mathrm{e}}$ Afdeling, sectie C, $1^{\text {e }}$ blad, nrs. 15,15 bis, 17 e 18,1905 .) 
DE SPIJKER AAN DE PENSMARKT

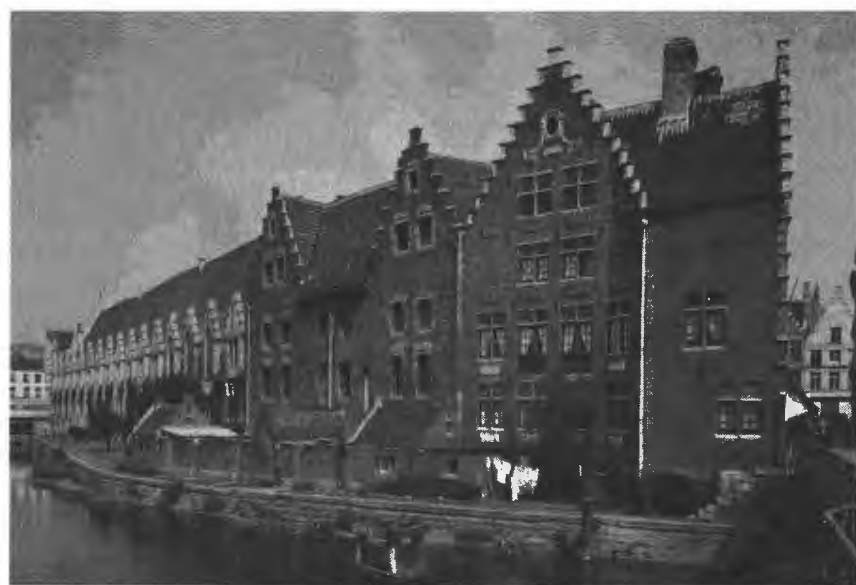

Afbeelding 27 Met de restauratie van de achtergevel werd de historische omgeving van het Groot Vleeshuis hersteld (KIK., Foto, objectnummer 123005, clichénummer B 48261) 